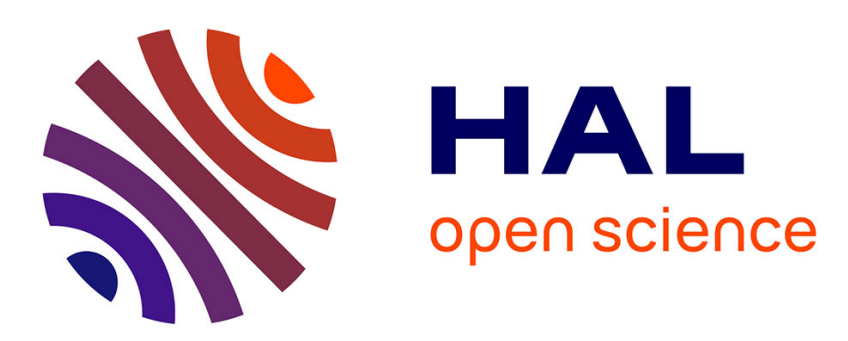

\title{
Yttrium promoted Ni-based double-layered hydroxides for dry methane reforming
}

\author{
Katarzyna Świrk, Maria Elena Gálvez, Monika Motak, Teresa Grzybek,
} Magnus Rønning, Patrick da Costa

\section{To cite this version:}

Katarzyna Świrk, Maria Elena Gálvez, Monika Motak, Teresa Grzybek, Magnus Rønning, et al.. Yttrium promoted Ni-based double-layered hydroxides for dry methane reforming. Journal of CO2 Utilization, 2018, 27, pp.247-258. 10.1016/j.jcou.2018.08.004 . hal-02307321

\section{HAL Id: hal-02307321 \\ https://hal.sorbonne-universite.fr/hal-02307321}

Submitted on 7 Oct 2019

HAL is a multi-disciplinary open access archive for the deposit and dissemination of scientific research documents, whether they are published or not. The documents may come from teaching and research institutions in France or abroad, or from public or private research centers.
L'archive ouverte pluridisciplinaire HAL, est destinée au dépôt et à la diffusion de documents scientifiques de niveau recherche, publiés ou non, émanant des établissements d'enseignement et de recherche français ou étrangers, des laboratoires publics ou privés. 


\section{Yttrium promoted Ni-based double-layered hydroxides for dry methane reforming}

Katarzyna Świrk ${ }^{1,2}$, Maria Elena Gálvez ${ }^{1}$, Monika Motak ${ }^{2}$, Teresa Grzybek ${ }^{1}$, Magnus Rønning $3^{*}$, Patrick Da Costa ${ }^{1 *}$

${ }^{1}$ Sorbonne Université, Institut Jean Le Rond d'Alembert, CNRS, 2 Place de la Gare de Ceinture, F-78210, Saint-Cyr-l'École, France

${ }^{2}$ AGH University of Science and Technology, Faculty of Energy and Fuels, Adama Mickiewicza Avenue 30, 30-059, Cracow, Poland

${ }^{3}$ Norwegian University of Science and Technology, Department of Chemical Engineering, Sem Sælandsvei 4, N-7491, Trondheim, Norway

Corresponding authors

* Patrick Da Costa, patrick.da costa@upmc.fr, ,+33 0130854862

* Magnus Rønning, magnus.ronning@ntnu.no, +47 73594121 


\begin{abstract}
Yttrium modified Ni-based double-layered hydroxides were tested as novel catalysts in dry methane reforming. The catalysts were characterized by XRF, BET analysis, XRD, TPR-H 2 , TPD$\mathrm{CO}_{2}$, TGA/DSC-MS, $\mathrm{H}_{2}$ chemisorption and TEM. Co-precipitation with yttrium (III) nitrate hexahydrate resulted in increased specific surface area, smaller Ni crystallite size, enhanced reducibility, and higher distribution of weak and medium basic sites as compared to Y-free material. The DRM catalytic tests, carried out in the temperature range of $850-600{ }^{\circ} \mathrm{C}$, led to a significant improvement of activity, with the $1.5 \mathrm{wt} \%$ Y-promoted catalyst being the most efficient in converting both $\mathrm{CH}_{4}$ and $\mathrm{CO}_{2}$. Moreover, the $10 \mathrm{~h}$ test at $700{ }^{\circ} \mathrm{C}$ further confirmed enhanced stability for this HTNi-Y1.5 catalyst. Higher $\mathrm{CO}_{2}$ conversion than $\mathrm{CH}_{4}$ conversion and less $\mathrm{CO}$ compared to $\mathrm{H}_{2}$ proves that side reactions are occurring simultaneously.
\end{abstract}

\title{
Keywords
}

dry reforming of methane, carbon dioxide, nickel, yttrium, double-layered hydroxides 


\section{Introduction}

Dry methane reforming (DRM), also called $\mathrm{CO}_{2}$ reforming, is considered one of the promising processes for chemical $\mathrm{CO}_{2}$ utilization [1-6]. DRM leads to synthesis gas, a mixture of hydrogen and carbon monoxide, that is currently used as feedstock in liquid fuel production processes, such as Fischer-Tropsch or methanol synthesis [7]. Nowadays, syngas is traditionally produced through steam methane reforming (SMR) [5]. Still, SMR yields a syngas with a far too high $\mathrm{H}_{2} / \mathrm{CO}$ ratio and needs to be consequently pre-treated when used in liquid fuel synthesis. For instance, the production of dimethyl ether requires $\mathrm{H}_{2} / \mathrm{CO}$ ratio close to unity [2]. This value can be easily obtained through dry methane reforming. In spite of this, DRM has not yet been fully launched on industrial scale because of its large demand for energy and the lack of active, selective and stable catalysts [3].

Ni-based catalysts seem to be good candidates for DRM due to their availability, low cost and good catalytic performance [8,9]. However, the main drawback for their application is susceptibility to carbon formation leading to fast deactivation $[3,4,6,10]$. The methods proposed to improve stability of Ni-based catalysts, include, among others, the addition of a second metal and/or a promoter, or the choice of an appropriate support. The proposed second metal may be either a noble metal (Pt, Ru, Rh, or Ir) or a transition metal (e.g. Co or Zn) [3,11-14].

$\mathrm{Ni} / \mathrm{Al}_{2} \mathrm{O}_{3}$ catalysts have been widely studied in DRM, yielding satisfactory catalytic activity due to the textural properties of alumina [15]. However, severe deactivation attributed to carbon formation and/or sintering of the active phase was observed [4][9]. On the other hand, the presence of a $\mathrm{NiO}-\mathrm{MgO}$ solid solution is known to enhance resistance of nickel particles towards sintering and to inhibit carbon formation [16]. Additionally, with the increase of $\mathrm{MgO}$ loading, higher coking resistance was reported for $\mathrm{Ni}-\mathrm{MgO}-\mathrm{Al}_{2} \mathrm{O}_{3}$ catalysts [17]. 
Double-layered hydroxides (DLHs) can be the source of prospective DRM catalyst supports, due to their layered structure and possible di- and/or tri-valent cations introduction into the layers, such as $\mathrm{Mg}^{2+}, \mathrm{Ni}^{2+}, \mathrm{Co}^{2+}, \mathrm{Zn}^{2+}$ and/or $\mathrm{Fe}^{3+}, \mathrm{Cr}^{3+}, \mathrm{Al}^{3+}$. Interlayer anions, e.g. water molecules and/or carbonates, compensate the positive charge and they may also be exchanged for catalytically active components [3,14,18-22]. Moreover, acid-base properties can be tailored, as reported e.g. for calcined NiMgAl-hydrotalcites by Pavel et al. [23] Basic properties, memory effect, and ability to exchange anions make them good catalysts and adsorbents [3][19]. Ni-containing double layered hydroxides were found to be active in the DRM $[3,14,24-30]$. After appropriate thermal treatment DLHs form nano-oxides whose strong interaction hinders Ni from sintering at high temperatures required for DRM [30]. It was also found that the stability of Ni-loaded hydrotalcite catalysts in DRM was enhanced by the addition of an appropriate promoter. Ce was reported to promote oxidation of carbon deposits through the Boudouard reaction [31,32], while Zr inhibited reactions leading to the formation of carbon deposits[14][25]. Lanthanum promotion contributed to carbon gasification which was assigned to the formation of $\mathrm{La}_{2} \mathrm{O}_{2} \mathrm{CO}_{3}$ [27].

Nevertheless, novel catalysts with enhanced selectivity and stability for DRM need to be developed, and promotion with metals may highly contribute to the improvement of catalytic properties. Yttrium is a rare-earth element that has recently attracted large interest for catalytic applications. As reported by Francis and Whitlow [33] yttrium oxides show high temperature oxidation resistance in the presence of carbon dioxide. Additionally, yttrium oxide has been studied as a support for DRM catalysts [34,35]. However, there are only a few literature reports describing the role of yttrium as a possible promoter in the DRM reaction [36-39]. Li et al. [36] observed high resistance towards carbon deposition for Y-promoted Ni-SBA-15 catalysts, which was attributed to high dispersion of yttrium with nickel nanoparticles, and the ability of yttrium to create oxygen 
vacancies. Similar properties were also observed in $\mathrm{Y}-\mathrm{Ce}_{0.75} \mathrm{Zr}_{0.25} \mathrm{O}_{2}$ catalysts [37]. Taherian et al. [39] reported a positive influence on controlling the nickel size and its dispersion into the mesopores of Ni/SBA-15 catalyst after modification with $\mathrm{Y}_{2} \mathrm{O}_{3}$. Moreover, in our previous study Ni-Y/KIT-6 catalyst exhibited better dispersion of nano-sized Ni particles inside the pores of the support as compared to Ni/KIT-6 material [38]. Also, the formation of coke was lower for Ymodified catalyst in the initial stability test at $700{ }^{\circ} \mathrm{C}$. Furthermore, B. Li et al. [40] studied $\mathrm{Ni} / \mathrm{Y} / \mathrm{Al}_{2} \mathrm{O}_{3}$ catalyst with yttrium introduced via different types of impregnation, and observed improved stability of the modified samples. However, in a recent study by Huang et al. [41] the impregnated NiO- $\mathrm{Y}_{2} \mathrm{O}_{3}-\mathrm{Al}_{2} \mathrm{O}_{3}$ mesoporous catalysts were reported to be less stable than the samples prepared with a one-pot evaporation-induced self-assembly method. The former resulted in the creation of loosely attached $\mathrm{Ni}$ particles on the support, which was the reason for fast deactivation of the catalyst due to graphitic carbon formation. The second method revealed the presence of $\mathrm{Ni}$ particles strongly anchored to the $\mathrm{Al}_{2} \mathrm{O}_{3}$ support. This resulted in an improvement of catalytic activity and stability. Additionally, the best results were obtained for a catalyst containing ca. 2 wt $\%$ of yttrium, which was attributed to the high surface area, small nickel particles and very high nickel dispersion.

To the best of our knowledge, no studies concerning the influence of yttrium on Ni-Mg-Al double-layered hydroxides have been reported in the literature. Only a few studies have dealt with Mg-Al hydrotalcites modified with Y for expoxidation [42], cyanoethylation [43] and aldol condensation [44].

The aim of this work was to prepare novel double-layered hydroxide-derived catalysts containing yttrium (0.6 and $1.5 \mathrm{wt} \%)$, and to examine the influence of Y promotion on the final physico- 
chemical properties of the resulting catalysts, their structure and performance in DRM in comparison to the corresponding thermodynamic equilibrium.

2. Thermodynamic equilibrium analysis

2.1. Minimization of Gibbs free energy

The Gibbs free energy analysis was used to study the equilibrium of the system containing several species. The total Gibbs free energy is expressed as [45-47]:

$$
G_{\text {total }}=\sum_{i=1}^{N} n_{i}\left[G_{i}^{0}+R T \ln \left(\frac{f_{i}}{f_{0}}\right)\right]
$$

Where the $G_{i}{ }^{0}$ is standard Gibbs free energy of formation of species $i, R$ stands for molar gas constant, $T$ is temperature of the system, and a number of moles is assigned to $n_{i}$ of species $i$. Standard-state is expressed as $25^{\circ} \mathrm{C}$ and 1 atm, while $f_{i}^{o}$ is a fugacity at this state of species $i$, and $f_{i}$ refers to operating state. In view of equation (1), $n_{i}$ moles of species has to fulfill the following relation:

$$
\sum_{i=1}^{N} a_{j i} n=b_{j}
$$

Where the number of element $j$ expressed in grams or atoms of molecule $i$ is assigned to $a_{j i}$. $b_{j i}$ is a total number of moles of element $j$ in the feed. Additionally, the following equality: $1 \leq \mathrm{j} \leq \mathrm{M}$, where $M$ is the number of elements in the mixture, has to be fulfilled.

\subsection{Calculation method}

Thermodynamic calculations were carried out by HSC Chemistry 5 software. The minimization of Gibbs free energy method was used. The influence of temperature and feed gas composition 
were examined in an isobaric system in order to calculate the equilibrium amount of $\mathrm{CO}_{2}, \mathrm{CH}_{4}, \mathrm{CO}$, $\mathrm{H}_{2}, \mathrm{H}_{2} \mathrm{O}, \mathrm{C}$, and equilibrium conversions of $\mathrm{CO}_{2}, \mathrm{CH}_{4}$, and $\mathrm{H}_{2} / \mathrm{CO}$ molar ratio.

For the calculations, the chemical reactions in methane reforming processes were considered (Table 1) $[45,48,49]$. The following reactants were taken into account: $\mathrm{Ar}_{(\mathrm{g})}, \mathrm{CH}_{4(\mathrm{~g})}, \mathrm{CO}_{2(\mathrm{~g})}, \mathrm{CO}_{(\mathrm{g})}$, $\mathrm{H}_{2(\mathrm{~g})}, \mathrm{H}_{2} \mathrm{O}_{(\mathrm{g})}, \mathrm{C}_{(\mathrm{s})}, \mathrm{C}_{2} \mathrm{H}_{2(\mathrm{~g})}, \mathrm{C}_{2} \mathrm{H}_{4(\mathrm{~g})}, \mathrm{C}_{2} \mathrm{H}_{6(\mathrm{~g})}, \mathrm{CH}_{3} \mathrm{OCH}_{3(\mathrm{~g})}, \mathrm{CH}_{3} \mathrm{OH}_{(\mathrm{g})}, \mathrm{HCOOH}_{(\mathrm{g})}$, while the substrates were assumed as: $\mathrm{CH}_{4(\mathrm{~g})}, \mathrm{CO}_{2(\mathrm{~g})}$ and $\mathrm{Ar}_{(\mathrm{g})}$. All calculations were performed with constant pressure of 1 bar.

\subsection{Equilibrium plots}

Fig. 1 presents equilibrium amount of reactants as a function of temperature for dry methane reforming $\left(\mathrm{CO}_{2} / \mathrm{CH}_{4} / \mathrm{Ar}=1 / 1 / 8, \mathrm{p}=1\right.$ bar $)$. The results are in good agreement with other authors' work [50,51]. Due to the endothermic nature of the process, and accompanied by parallel reactions, a large variation in the quantity of components while temperature increase (from 0 to $1000{ }^{\circ} \mathrm{C}$ ) is observed. In the middle of the temperature range (at $500^{\circ} \mathrm{C}$ ) a large amount of carbon is formed, together with water, and greater amount of $\mathrm{H}_{2}$ with respect to $\mathrm{CO}$. The $\mathrm{CO}_{2}$ equilibrium reaches a maximum peak at $500{ }^{\circ} \mathrm{C}$, which refers to the lowest conversion of this gas in the entire temperature range (0-1000 $\left.{ }^{\circ} \mathrm{C}\right)$ (Fig. 2). This suggests a very likely occurrence of other parallel reactions than just the dry reforming. Above this temperature (ca. $600{ }^{\circ} \mathrm{C}$ and more), a fast decrease in carbon and water formation is observed. In addition, $\mathrm{H}_{2}$ and $\mathrm{CO}$, which represent a sufficient value of molar ratio (around 1) for further fuel production (Fig. 2), are observed. It is consistent that DRM likely occurs at very high temperature $\left(<700{ }^{\circ} \mathrm{C}\right)$, although from the economical point of view it would be desirable to run the process at slightly lower temperature with a very active and stable catalyst. 


\section{Experimental}

\subsection{Catalysts synthesis}

The double-layered hydroxides were synthesized by a co-precipitation method using aqueous solutions of $\mathrm{Mg}\left(\mathrm{NO}_{3}\right)_{2} \cdot 6 \mathrm{H}_{2} \mathrm{O}$ (Sigma Aldrich, 99\% pure), $\mathrm{Ni}\left(\mathrm{NO}_{3}\right)_{2} \cdot 6 \mathrm{H}_{2} \mathrm{O}$ (Sigma Aldrich, $98.5 \%$ pure), $\mathrm{Al}\left(\mathrm{NO}_{3}\right)_{3} \cdot 9 \mathrm{H}_{2} \mathrm{O}$ (Fluka, 98\% pure) and $\mathrm{Y}\left(\mathrm{NO}_{3}\right)_{3} \cdot 6 \mathrm{H}_{2} \mathrm{O}$ (Aldrich, $99.8 \%$ pure). The molar ratios of $\mathrm{Ni}^{2+} / \mathrm{Mg}^{2+}$ and $\mathrm{M}^{2+} / \mathrm{M}^{3+}$ were adjusted to 0.33 and ca. 3.0, respectively. Catalysts preparation aimed at the following content of yttrium in the individual samples: 0.6 and $2.0 \mathrm{wt} \%$. As described further in the text the introduced amounts of yttrium were 0.6 and $1.5 \mathrm{wt} \%$, and thus the samples were designated HTNi-Y0.6 and HTNi-Y1.5. The mixture of the salts was added dropwise to the $0.05 \mathrm{M}$ sodium carbonate solution (AnalaR NORMAPUR, $99.9 \%$ pure), which was vigorously mixed and heated to $65^{\circ} \mathrm{C}$. The $\mathrm{pH}$ during the co-precipitation was kept at $10 \pm 0.2$ by using $2 \mathrm{M}$ solution of $\mathrm{NaOH}$. The mixture was allowed to react for $24 \mathrm{~h}$. Then the slurry was filtered, washed with distilled water and dried overnight at $80^{\circ} \mathrm{C}$. The catalysts were subsequently calcined in air at $550{ }^{\circ} \mathrm{C}$ for $5 \mathrm{~h}$.

\subsection{Catalysts characterization}

3.2.1. Elemental composition, structural parameters, and textural properties of catalysts

The elemental composition analysis was performed through Wavelength Dispersive X-Ray Fluorescence (WDXRF) in a Supermini200 analyzer. The analysis was carried out under vacuum at $36.5^{\circ} \mathrm{C}$. A proportional counter detector $(\mathrm{PC})$ was used during experiments with the presence of P-10 gas (mixture of $10 \% \mathrm{CH}_{4} / \mathrm{Ar}$ ) with flow of $24.7 \mathrm{~cm}^{3} / \mathrm{min}$. Before each experiment a pulse height analyzer (PHA) was adjusted to calibrate the detector. Samples were diluted in boric acid 
with a ratio of 1:40, and subsequently pelletized under pressure of 10 bar. The pellet was inserted between the sample retainer and sample holder and covered with $6 \mu \mathrm{m}$ polypropylene film.

The structure and phase composition of the catalysts were examined by X-ray diffraction (PANalytical-Empyrean diffractometer, equipped with $\mathrm{CuK} \alpha$ of $\lambda=0.15406 \mathrm{~nm}$ radiation source). The average crystallite size of Ni was determined from the Scherrer equation ( $\mathrm{K}$ shape factor=0.9) [52].

Textural properties were derived from low temperature $\mathrm{N}_{2}$ adsorption measurements at $-195{ }^{\circ} \mathrm{C}$ using a Micromeritics TriStar II 3020. Prior to the test, $100 \mathrm{mg}$ of calcined sample was outgassed at $110^{\circ} \mathrm{C}$ for $3 \mathrm{~h}$. The Brunauer-Emmett-Teller (BET) method was used to calculate specific surface area, while pore diameter and pore volume were obtained from the Barrett-Joyner-Halenda (BJH) method.

\subsubsection{Reducibility, basicity, Ni dispersion and crystallite size}

The reducibility of calcined samples was determined by temperature-programmed reduction $\left(\mathrm{TPR}-\mathrm{H}_{2}\right)$ measurements, which were carried out in a BEL Japan BELCAT-M, equipped with a thermal conductivity detector (TCD). $60 \mathrm{mg}$ of each catalyst was first degassed in helium at 100 ${ }^{\circ} \mathrm{C}$ for $2 \mathrm{~h}$, and then reduced with $5 \% \mathrm{H}_{2} / \mathrm{Ar}$ mixture in the temperature range from 100 to $900{ }^{\circ} \mathrm{C}$ with a heating rate of $7.5^{\circ} \mathrm{C} / \mathrm{min}$.

The basic properties of the samples were examined by temperature programmed desorption of carbon dioxide. The TPD- $\mathrm{CO}_{2}$ measurement was performed just after the $\mathrm{TPR}-\mathrm{H}_{2}$ measurement, using the same apparatus. $\mathrm{CO}_{2}$ was adsorbed from a mixture of $10 \% \mathrm{CO}_{2}$ in $\mathrm{He}$. Subsequently, the weakly physically adsorbed carbon dioxide was desorbed in a flow of He for 15 min. Finally, the samples were heated from $80{ }^{\circ} \mathrm{C}$ to $800{ }^{\circ} \mathrm{C}$ in helium $\left(10{ }^{\circ} \mathrm{C} / \mathrm{min}\right)$. In order to determine basicity, 
the obtained peaks were fitted by Gaussian contributions. The distribution of weak, middle and strong basic sites, was calculated based on the area of the fitted peaks.

The $\mathrm{H}_{2}$ chemisorption was performed to determine nickel dispersion on reduced samples. The results were obtained using a Micrometrics ASAP 2020 instrument. Prior to the analysis, $200 \mathrm{mg}$ of a calcined sample was evacuated in the He flow at $40{ }^{\circ} \mathrm{C}$ for $1 \mathrm{~h}$. Then, the reduction step occurred for the next hour in pure $\mathrm{H}_{2}$ at $900{ }^{\circ} \mathrm{C}$. Afterwards, the second evacuation step was carried out under the same conditions as the first time. Finally, an analysis was performed in the flow of pure $\mathrm{H}_{2}$ at $40{ }^{\circ} \mathrm{C}$.

\subsubsection{Stability of the catalysts and carbon formation}

The TGA/DSC-MS (STA 449C Jupiter TGA/DSC and Netzsch Aërlos QMS 403 MS) tests were performed on spent catalysts in order to calculate the mass loss and determine the thermal character of the reactions taking place during catalysts decomposition conducted in air with a heating rate of $10{ }^{\circ} \mathrm{C} / \mathrm{min} .8 \mathrm{mg}$ of each sample was studied as a function of temperature (from room temperature to $\left.900{ }^{\circ} \mathrm{C}\right)$. During mass spectroscopy analysis, the following gases were registered; m/e: $44\left(\mathrm{CO}_{2}\right)$ and $18\left(\mathrm{H}_{2} \mathrm{O}\right)$.

The micrographs obtained from Transmission Electron Microscopy (TEM, JOEL JEM-100XCII) were used for the determination of $\mathrm{Ni}$ crystallite size distribution, and the type of formed carbon in the spent catalysts. The samples were prepared by dropwise addition of a colloidal solution in ethanol onto a copper grid covered with amorphous carbon film. 400 particles were measured in the ImageJ software in order to obtain the average Ni particle size in the spent catalysts. 


\subsection{Catalytic performance in dry reforming of methane}

The catalytic tests were carried out in a fixed-bed flow reactor. A thermocouple type K was used to control the temperature, which was in contact with catalytic bed, protected by quartz shield. Before the catalytic test, the samples were reduced in situ at $900{ }^{\circ} \mathrm{C}$ for $1 \mathrm{~h}$ with a $5 \% \mathrm{H}_{2} / \mathrm{Ar}$ gas mixture (heating rate $10{ }^{\circ} \mathrm{C} / \mathrm{min}$, flow $50 \mathrm{ml} / \mathrm{min}$ flow). Then the tests were performed in the temperature range of $850-600{ }^{\circ} \mathrm{C}$ for every $50{ }^{\circ} \mathrm{C}$ and cooling time of 15 min between the steps. The duration of the measurement at each temperature was 30 minutes. Within this time steady-state was obtained. The composition of the inlet gas mixture was $\mathrm{CH}_{4} / \mathrm{CO}_{2} / \mathrm{Ar}=1 / 1 / 8$ at $\mathrm{GHSV}=20,000$ $\mathrm{h}^{-1}$. The total flow was $100 \mathrm{~cm}^{3} / \mathrm{min}$. The outlet gases were analyzed by a gas chromatograph (490 Varian Micro-GC).

Time-on-stream experiments were carried out in order to check the stability of the prepared catalysts. The samples were reduced in situ with the mixture of $5 \% \mathrm{H}_{2} / \mathrm{Ar}$ for $1 \mathrm{~h}$. Then dry reforming was carried out at $700{ }^{\circ} \mathrm{C}$ for $5 \mathrm{~h}$ with the same gas feed composition and gas hourly space velocity as above.

The relative change of $\mathrm{CH}_{4}$ and $\mathrm{CO}_{2}$ conversions after 5 and $10 \mathrm{~h}$ tests were calculated by using the following formula (3):

$$
\Delta=\frac{x_{i}-x_{h}}{x_{i}} \cdot 100 \%
$$

Where $\Delta$ is relative conversion change, $x$ is conversion of $\mathrm{CH}_{4}$ or $\mathrm{CO}_{2}$ expressed in percentage, and subscripts stand for $i$ - initial, $h$ - after 5 or 10 hours.

The catalytic activity was also expressed as turnover frequency (TOF). The TOF values were calculated from equation (4), which represents the reaction rate per nickel active site.

$$
T O F=\frac{-r \cdot M}{3600 \cdot z \cdot D}
$$


Where the $-r$ is expressed in $\frac{m_{C H} l_{C H}}{g_{c a t} \cdot h}$, or $\frac{m l_{C O 2}}{g_{c a t} \cdot h} . M$ is nickel molar mass, $z$ stands for weight fraction of nickel, and $D$ is the dispersion obtained from $\mathrm{H}_{2}$ chemisorption.

4. Results and discussion

4.1. Characterization of the catalysts before dry methane reforming

4.1.1. Elemental composition, structural parameters, and textural properties

Table 2 shows the elemental composition of the calcined catalysts, as obtained by XRF. All samples have nickel content between 14 and $20 \mathrm{wt} \%$. The yttrium loading was the same as the nominal loading for HTNi-Y0.6, but not for the HTNi-Y1.5 sample. This catalyst contained $1.5 \mathrm{wt}$ $\%$ of $\mathrm{Y}$, instead of $2.0 \mathrm{wt} \%$ assumed during the preparation procedure. This suggests that only in case of lower Y contents, Y could be fully introduced into the structure of the double-layered hydroxides. The obtained $\mathrm{M}^{2+} / \mathrm{M}^{3+}$ atomic ratios were similar to the nominal value of 3.0 in all catalysts; however, the ratios of $\mathrm{Ni}^{2+} / \mathrm{Mg}^{2+}$ were close to 0.33 only in $\mathrm{HTNi}$ and HTNi-Y0.6 samples. The catalyst with $1.5 \mathrm{wt} \%$ of yttrium showed the value lower than 0.33 , i.e. 0.18 , indicating that $\mathrm{Mg}^{2+}$ ions were substituted only by a part of the assumed number of $\mathrm{Ni}^{2+}$ cations. On the other hand, the lower nickel content for this sample may also arise from possible substitution of $\mathrm{Ni}^{2+}$ by $\mathrm{Y}^{3+}$, as suggested by J.F. Li et al. [53] for yttrium promoted $\mathrm{NiO} / \mathrm{SBA}-15$ catalysts. In the latter case, this ion exchange contributed to the formation of oxygen vacancies, resulting in the elimination of carbon deposits.

The values for the lattice parameter $a$ and unit cell parameter $c$ (for uncalcined materials) are shown in Table 2. The obtained values of $c$, which refers to the triple distance between brucite-like layers, remained practically unchanged after Y-modification as compared to non-modified material. Pavel et al. [42] found an increase of $c$ parameter suggesting Y aggregation on the external 
surface, which is not the case in our study. The c' parameter, equal to one brucite-like sheet and one interlayer $\left(c^{\prime}=c / 3\right)$, is $7.8 \AA$ and constant for our HTNi-Y catalysts, indicating the presence of $\mathrm{CO}_{3}{ }^{2-}$ anions in the samples (7.65 $\AA$ ) [19]. Finally, the lattice parameter $a$ is also stable for all catalysts (3.06 ̊̊), although García-García et al. [54] assumed that the introduction of yttrium into DLHs layers, considering its ionic radius bigger than that of $\mathrm{Mg}$ and $\mathrm{Al}\left(\mathrm{Y}^{3+}=1.04 \AA \mathrm{Mg}^{3+}=0.86\right.$ $\AA, \mathrm{Al}^{3+}=0.675 \AA$ ) [55], may cause lattice distortions, i.e. changes in the lattice parameter $a$. On the other hand, Fernández et al. [55], reported that only yttrium loading higher than 4 wt \%, was a possible reason for distortions in the DLHs layers, recognised as very low crystallinity observed in XRD patterns. As the amount of Y introduced into our catalysts was much lower, the stability of the lattice parameter $a$ does not contradict the possibility of introduction of Y into the structure of double-layered hydroxides.

BET analysis for calcined samples revealed specific surface area values from 120 to $192 \mathrm{~m}^{2} / \mathrm{g}$, where the highest $\mathrm{S}_{\mathrm{BET}}$ was observed for HTNi-Y1.5, and the lowest for the non-modified catalyst (Table 2). As reported by Kim et al. [22] a partial crystal deformation of double-layered hydroxides occurs upon calcination, in which octahedral $\mathrm{Al}(\mathrm{OH})_{6}$ migrates to tetrahedral $\mathrm{AlO}_{4}$ resulting in the enhancement of $\mathrm{S}_{\mathrm{BET}}$. In our case, the increase in specific surface area can be linked with the creation of narrower pores in Y-modified materials. The total pore volume remained unchanged after modification with yttrium. However, pore diameters decreased as compared to non-modified HTNi catalyst. It shows that Y-promotion positively influences the textural properties of Ni-based catalyst, since a larger number of smaller pores are formed, and higher specific surface area is obtained. Similar effect was observed by Huang et al. [41], who reported that the modification of $\mathrm{NiO}-\mathrm{Al}_{2} \mathrm{O}_{3}$ supports with less than $3 \mathrm{wt} \%$ of yttrium increased the $\mathrm{S}_{\text {BET. }}$ This was further observed as beneficial for catalytic performance. 


\subsubsection{Reducibility, basicity, Ni crystallite size and dispersion}

Fig. 3 presents $\mathrm{TPR}-\mathrm{H}_{2}$ profiles for $\mathrm{Y}$-modified $\mathrm{Ni} / \mathrm{Mg} / \mathrm{Al}$ double-layered hydroxides. The profile for HTNi contains two wide peaks with maxima at 386 and $829^{\circ} \mathrm{C}$, which may be attributed to $\mathrm{NiO}$ weakly-bonded to the double-layered hydroxides structure and nickel oxides present in the mixed oxides structure of double-layered hydroxides, respectively $[14,27,31,56]$. The maximum temperature of the latter peak $\left(\mathrm{T}_{\max }\right)$ showed a shift to higher temperature after the yttrium addition, indicating stronger interaction of Ni species with the support as compared to HTNi catalyst. For 1.5 wt $\%$ of $\mathrm{Y}$, the shift in reducibility was less pronounced, as reflected in the lower temperature of the maximum $\left(858^{\circ} \mathrm{C}\right.$ ), as well as the presence of some weakly bonded $\mathrm{NiO}$ (minor maximum at $327^{\circ} \mathrm{C}$ ). The higher $\mathrm{T}_{\max }$, together with the presence of $\mathrm{NiO}$, was observed before by Huang et al. [41] for NiO- $-\mathrm{Al}_{2} \mathrm{O}_{3}$ materials modified with $\mathrm{Y}_{2} \mathrm{O}_{3}$. Dependence of $\mathrm{T}_{\max }$ similar to that observed for our samples, was also reported in the study of Dębek et al. [57] for Zr-modified double-layered hydroxides. Lower amount of added zirconia resulted in a decrease of reducibility, in contrast to modification with higher $\mathrm{ZrO}_{2}$ loading for which a reducibility increase was observed. The authors ascribed it to the location of $\mathrm{ZrO}_{2}$ in the structure of hydrotalcite or on the outside. Higher loading of zirconia led to its deposition outside the periclase structure, i.e. on the surface, resulting in weaker interactions with $\mathrm{Ni}$, and presence of weakly bonded $\mathrm{NiO}$, as it is observed in our study.

Hydrogen consumption for the reduced samples is presented in Fig. 3. The highest consumption of $0.209 \mathrm{mmol} \mathrm{H}_{2} / \mathrm{g}$ was observed for non-modified HTNi catalyst. After promotion with yttrium, the values of hydrogen consumption decreased to $0.145 \mathrm{mmol} \mathrm{H}_{2} / \mathrm{g}_{\text {cat }}$ and $0.165 \mathrm{mmol} \mathrm{H}_{2} / \mathrm{g}$ for HTNi-Y0.6 and HTNi-Y1.5 catalysts, respectively. The somewhat higher $\mathrm{H}_{2}$ uptake in the HTNi sample, together with lower maximum temperature of reduction as compared to yttrium-containing 
catalysts, may be due to the weaker interaction between $\mathrm{Ni}$ and the support, as well as the presence of $\mathrm{NiO}$ loosely attached to the surface for the former sample.

Basicity of the reduced samples is shown in Fig. 4. Three types of basic sites could be distinguished with maxima at (i) $135-142{ }^{\circ} \mathrm{C}$, (ii) $203-218{ }^{\circ} \mathrm{C}$ and (iii) $316-367{ }^{\circ} \mathrm{C}$, respectively. They are ascribed to weak (Brønsted basic sides, such as hydroxyl groups), medium (Lewis acidbase sites), and strong basic sites (Lewis basic sites associated with oxygen anions) [27,31]. The data in Table 3 show that total basicity was highest for the non-modified Ni-hydrotalcite-derived catalyst, and similar in value to a comparable HT-25Ni catalyst studied by Dębek et al. [26], which was found to have optimal basicity for DRM. The addition of Y modified both the number and the distribution of basic sites. The total basicity decreased after yttrium addition, showing the lowest value of $55.8 \mu \mathrm{mol} / \mathrm{g}$ for HTNi-Y0.6, and slightly higher for HTNi-Y1.5 sample, i.e. $77.1 \mu \mathrm{mol} / \mathrm{g}$. The amount of each type of sites (weak, medium and strong) in the HTNi-Y materials studied in this work also decreased compared to HTNi. For the HTNi-Y samples the site distribution shifted towards medium and weak sites, at the expense of strong sites; expressed as a higher sum of weak and medium sites for HTNi-Y0.6 and HTNi-Y1.5 catalysts (79.6 and 61.6\%, respectively) compared to the sum calculated for HTNi (56.6\%). This may have positively influenced DRM catalytic performance, which will be discussed further.

Fig. 5 shows XRD patterns of the reduced catalysts, where characteristic reflections for metallic nickel $\left(\mathrm{Ni}^{0}\right)\left(2 \Theta\right.$ ca. $\left.44.5^{\circ}, 53^{\circ}, 76.5^{\circ}\right)$ corresponding to crystal planes of (111), (200), (220) and periclase mixed oxides $\left(2 \Theta\right.$ ca. $\left.36.7^{\circ}, 43^{\circ}, 62.5^{\circ}\right)$ are observed. $[27,31,38,58]$ Table 4 compares the size of Ni particles, calculated from the $2 \Theta$ diffraction peak at ca. $53^{\circ}$ using the Scherrer equation. It may be seen that the yttrium addition results in a decrease of nickel crystallites from ca. $8 \mathrm{~nm}$ for the unpromoted HTNi to ca. $6 \mathrm{~nm}$ for HTNi-Y (Table 4). A similar effect was observed for the Ni- 
$\mathrm{Y}-\mathrm{Al}_{2} \mathrm{O}_{3}$ samples and better performance in DRM was attributed to the formation of these smaller Ni particles $[40,41]$.

Fig. 6 shows TEM micrographs for the reduced samples, where also smaller particle sizes were registered for Y-promoted catalysts. The average particle size varies from $27 \mathrm{~nm}$ for the unpromoted $\mathrm{HTNi}$, to $16 \mathrm{~nm}$ and $14 \mathrm{~nm}$ for HTNi-Y0.6 and HTNi-Y1.5, respectively (Table 4).

The reason for obtaining higher values from TEM analysis, as compared to XRD, may lie in differences in measurement techniques. By TEM, the particle size of all nickel aggregates is measured, irrespective if they are crystallite or amorphous. On the other hand, XRD data gives information only on nickel particles with high crystallinity. The nickel crystallite diameters were also calculated based on $\mathrm{H}_{2}$ chemisorption data, assuming uniform spherical particles. The values varied from 11, to 5 and $5 \mathrm{~nm}$ for $\mathrm{HTNi}, \mathrm{HTNi}-\mathrm{Y} 0.6$ and HTNi-Y1.5, respectively (Table 4), and are in good agreement with values calculated from XRD.

The Ni crystallite size, calculated through these three characterization techniques, clearly show a decrease in Ni particle size with Y addition (Table 4). The accuracy of these techniques was examined by Mustard et al. [59]. The authors described the application of TEM, $\mathrm{H}_{2}$ adsorption and XRD for the determination of $\mathrm{Ni}$ crystallite size in supported catalysts, such as $\mathrm{Ni} / \mathrm{SiO}_{2}, \mathrm{Ni} / \mathrm{Al}_{2} \mathrm{O}_{3}$ and $\mathrm{Ni} / \mathrm{TiO}_{2}$. As stated by the authors, the precision of each technique depends on $\mathrm{Ni}$ loading and its dispersion, as well as the textural properties of used support.

The dispersion of metallic nickel calculated from $\mathrm{H}_{2}$ chemisorption is shown in Table 5. A positive influence of yttrium promotion resulting in higher $\mathrm{Ni}$ dispersion may be clearly seen, as the dispersion values are $8.9 \%, 17.7 \%$ and $19.8 \%$ for HTNi, HTNi-Y0.6 and HTNi-Y1.5, respectively. As reported by Huang et al. [41], better dispersion of nickel benefits catalytic 
performance in dry reforming of methane since a higher number of accessible metallic sites are created on the surface of the catalyst.

4.2. Catalytic performance in dry reforming of methane and stability tests

Fig. 7A and 7B present the $\mathrm{CH}_{4}$ and $\mathrm{CO}_{2}$ conversions for DRM as a function of temperature. The yttrium promotion positively affects the activity of Ni-containing double-layered hydroxides. The non-modified HTNi has the lowest activity, both for $\mathrm{CH}_{4}$ and $\mathrm{CO}_{2}$ conversions (Fig. 7A, 7B). The addition of $\mathrm{Y}$ significantly improves both conversions, and a correlation between the increase of catalytic activity and the increasing $\mathrm{Y}$ content can be observed. Table 5 presents the catalytic activity results for the tested catalysts. The values of $\mathrm{CH}_{4}$ conversion at $700{ }^{\circ} \mathrm{C}$ obtained for $\mathrm{HTNi}$, HTNi-Y0.6 and HTNi-Y1.5 catalysts were $66 \%, 74 \%$ and $76.2 \%$, respectively. For $\mathrm{CO}_{2}$ conversion, the following results were obtained: $76 \%, 78 \%$ and $80.8 \%$ for respectively $\mathrm{HTNi}$, HTNi-Y0.6 and HTNi-Y1.5 catalysts. The same activity sequence was observed at $750{ }^{\circ} \mathrm{C}$ (Table 5). Within this series of double-layered hydroxide-derived catalysts, the one promoted with $1.5 \mathrm{wt}$ $\% \mathrm{Y}$ is the most efficient in the whole temperature range during the experiment (Fig. 7A, 7B). The similar trend was observed in $\mathrm{H}_{2} / \mathrm{CO}$ molar ratio (Fig. 7C), where higher values were obtained for Y-modified samples than for HTNi. However, for the promoted samples, the differences in the produced $\mathrm{H}_{2} / \mathrm{CO}$ ratios were significant only at the lowest studied temperature of $600{ }^{\circ} \mathrm{C}$. Most probably, other side reactions started to be more dominant than the dry reforming reaction, resulting in a slowly increasing fraction of $\mathrm{CO}$ compared to $\mathrm{H}_{2}$.[39]

Table 5 shows additionally turnover frequencies (TOF) calculated at 700 and $750{ }^{\circ} \mathrm{C}$. Comparing HTNi with HTNi-Y1.5 we can observe higher value of TOF for the latter sample, which is in agreement with the better nickel dispersion (19.8\% versus $9.8 \%$ for Y-free catalyst). However, 
considering the results of $\mathrm{Ni}$ dispersion and the turnover frequencies calculations, the performance differences between HTNi and HTNi-Y0.6 cannot be easily explained. Most probably, the promotion with $0.6 \mathrm{wt} \%$ of yttrium is not enough to change the properties of the catalyst.

The stability experiments were carried out at $700{ }^{\circ} \mathrm{C}$ and, as given in Table 6 , showed initial $\mathrm{CH}_{4}$ conversions of $74.0 \%, 73.9 \%$, and $74.4 \%$ respectively for HTNi, HTNi-Y0.6 and HTNi-Y1.5. Initial $\mathrm{CO}_{2}$ conversion increased for the higher loading of yttrium in the tested samples: $75.7 \%$ for $\mathrm{HTNi}<78.1 \%$ for HTNi-Y0.6 $<78.6 \%$ for HTNi-Y1.5. All samples showed relatively stable conversion values after 5 hours (300 min) (Fig. 8A-C). However, the relative changes in $\mathrm{CH}_{4}$ and $\mathrm{CO}_{2}$ conversions were the lowest for HTNi-Y1.5 catalyst, indicating that this was the most stable among the studied catalysts (cp. Table 6). Moreover, after 10 hours (600 min) of DRM test (Fig. 8A-C), the following relative change in $\mathrm{CH}_{4}$ conversion was obtained: 4.8, 4.9 and 1.0 for $\mathrm{HTNi}$, HTNi-Y0.6 and HTNi-Y1.5 catalysts, respectively (Table 6). A similar trend could be observed for relative change in $\mathrm{CO}_{2}$ results, i.e. 5.5, 6.6, 1.5 for $\mathrm{HTNi}, \mathrm{HTNi}-\mathrm{Y} 0.6$ and $\mathrm{HTNi}-\mathrm{Y} 1.5$ catalysts, respectively. This confirms enhanced stability of HTNi-Y1.5 compared to the other tested catalysts. Similarly, as observed for activity tests, the highest conversions were observed for HTNi-Y1.5. $\mathrm{H}_{2} / \mathrm{CO}$ molar ratio was also highest for the $1.5 \mathrm{wt} \%$ Y-promoted catalyst (Fig. 8C). Some differences may be observed in the registered $\mathrm{H}_{2} / \mathrm{CO}$ ratio for $\mathrm{HTNi}$ and $\mathrm{HTNi}-\mathrm{Y} 0.6$ catalysts, where the values measured in the activity test and stability tests are compared. These dissimilarities may come from the methodology of the experiments, due to a possible slight initial deactivation of the catalysts, which were examined in the activity tests at the temperature higher than $700{ }^{\circ} \mathrm{C}$.

The positive effect of the $\mathrm{Y}$ promotion was also observed for $\mathrm{Ni}, \mathrm{Y}-\mathrm{Al}_{2} \mathrm{O}_{3}[40]$, Ni-Y/SBA-15 [36,39], Ni-Y/KIT-6 [38], NiO- $\mathrm{Y}_{2} \mathrm{O}_{3}-\mathrm{Al}_{2} \mathrm{O}_{3}$ [41] and $\mathrm{Y}-\mathrm{Ce}_{0.75} \mathrm{Zr}_{0.25} \mathrm{O}_{2}$ [37]. Also, $\mathrm{CO}_{2}$ conversion was reported to be slightly higher than that of $\mathrm{CH}_{4}$, and the values of $\mathrm{H}_{2} / \mathrm{CO}$ ratio lower than 1 , 
which was ascribed to occurrence of the reverse water gas-shift side reaction $\left(\mathrm{CO}_{2}+\mathrm{H}_{2}=\mathrm{CO}+\mathrm{H}_{2} \mathrm{O}\right)$ $[5,7,10,38,39,41]$. Moreover, other side reactions such as gasification of carbon deposits and the Boudouard reaction could have taken place $[10,31,38]$. This agrees with catalytic results in this study $\left(\mathrm{CO}_{2}\right.$ conversion slightly higher than $\mathrm{CH}_{4}$ conversion, and $\mathrm{H}_{2} / \mathrm{CO}$ molar ratio less than 1). However, Li et al. [36] observed in SBA-15 supported catalysts with Y/Si ratio of 0.02, 0.06 and $0.08, \mathrm{CH}_{4}$ conversion higher than that of $\mathrm{CO}_{2}$, and ascribed it to methane decomposition. No such result was registered in our study, which shows possible enhanced stability of the Y modified double-layered hydroxides. As reported by Dębek et al. [26] the methane decomposition (which causes catalyst deactivation) was less pronounced for smaller Ni particles. Thus, the fact that $\mathrm{Y}$ promotion results in smaller crystallites may play an important role in suppression of this unwanted reaction.

The yttrium modification resulted also in better dispersion of metallic $\mathrm{Ni}$, enhanced specific surface area, as well as in increased share of weak and medium basic sites compared to strong ones.

The better dispersion of nickel is of importance for catalytic performance, as better distribution of smaller Ni particles makes them more accessible to $\mathrm{CH}_{4}$ in DRM process. [41]. The increased specific surface area is another positive effect. As reported by Huang et al. [41] the textural properties of NiO- $\mathrm{Y}_{2} \mathrm{O}_{3}-\mathrm{Al}_{2} \mathrm{O}_{3}$ materials were linked with the behavior in $\mathrm{CO}_{2}$ reforming reaction, with good catalytic results for enhanced $\mathrm{S}_{\mathrm{BET}}$. On the other hand, the weak and medium basic sites may be also of advantage for DRM reaction rather than the strong sites, as suggested by Liu et al. [27]. Dębek et al. [26] found that enhanced basicity may hinder carbon formation and/or contribute to oxidation of formed coke. Additionally, the presence of the strongest basic sites may have a negative effect because of too strong $\mathrm{CO}_{2}$ adsorption, which results in carbon formation [14]. 
The mechanism of DRM can be shorty described as (i) decomposition of methane on Ni active site and (ii) dissociative adsorption of carbon dioxide on the metal surface and metal-surface interface $[60,61]$. During the first step, a carbon on the Ni surface is formed as a product of $\mathrm{CH}_{4}$ decomposition $\left(\mathrm{CH}_{4}=\mathrm{C}+2 \mathrm{H}_{2}\right)$. The carbon atom can be oxidized by atomic oxygen derived from $\mathrm{CO}_{2}$. It was reported that doping with $\mathrm{Y}^{3+}$ improved the rate of carbon removal due to oxygen vacancies, which persuaded oxygen radicals from $\mathrm{CO}_{2}$ to react with coke. $[35,39,53,62,63]$ Thus, a possible removal of carbon could have taken place according to the reverse Boudouard reaction $\left(\mathrm{CO}_{2}+\mathrm{C}=2 \mathrm{CO}\right)$. [53] The latter may be also linked with possible re-dispersion of the Ni particles (described further in the text). When the excess amount of oxygen is in close proximity to the $\mathrm{Ni}^{0}$ particles, it will lead to formation of $\mathrm{NiO}$, further reduced again to $\mathrm{Ni}^{0}$ due to $\mathrm{H}_{2}$ presence in the system. [61]

\subsection{Characterization of spent catalysts}

Fig. 9 shows TPR-H $\mathrm{H}_{2}$ profiles for catalysts after dry methane reforming tests. In contrast to the curves shown in Fig. 5, broad peak at around $850{ }^{\circ} \mathrm{C}$ disappeared, and only the low temperature peak was registered. This shows that nickel was not kept totally in reduced state throughout the dry reforming test. Some Ni species were oxidized during DRM, since peaks at ca. $300{ }^{\circ} \mathrm{C}$ and $500{ }^{\circ} \mathrm{C}$ arise from bulk $\mathrm{NiO}[14,27]$. On the other hand, no reflections of $\mathrm{NiO}$ were observed in the XRD patterns for the reduced and spent catalysts (Fig. 5 and Fig. 9), indicating that the size of $\mathrm{NiO}$ particles was below the XRD detection level due to e.g. their low crystallinity or high dispersion.

$\mathrm{H}_{2}$ consumption has been calculated for the spent catalysts, shown in Fig. 9. The obtained results are approximately four times lower compared to the values found for calcined samples, i.e. 0.036 $\mathrm{mmol} \mathrm{H} / \mathrm{g}_{\text {cat }}, 0.047 \mathrm{mmol} \mathrm{H} / \mathrm{g}_{\text {cat }}$ and $0.042 \mathrm{mmol} \mathrm{H}_{2} / \mathrm{g}_{\text {cat }}$ for HTNi, HTNi-Y0.6 and HTNi-Y1.5, 
respectively. The presence of reduction peaks in the spent materials shows that during DRM a redox mechanism may have taken place, in which Ni particles were continuously oxidized and reduced.

TGA/DSC-MS was carried out on the catalysts after the activity test. Fig. 10 presents the curves of mass loss. The registered mass loss was: HTNi (81.9\%), HTNi-Y0.6 (80.4\%), and HTNi-Y1.5 (75.8\%). The Y0.6 catalyst showed behavior different from HTNi and HTNi-Y1.5. For the former, the mass decline starts at around $500{ }^{\circ} \mathrm{C}$ in comparison to ca. $350{ }^{\circ} \mathrm{C}$ observed for other catalysts. Moreover, a small weight increase may be observed at $300{ }^{\circ} \mathrm{C}$ for all samples, which, as reported by Tsyganok et al. [64], arises from $\mathrm{Ni}^{0}$ oxidation to $\mathrm{NiO}$. The registered $\mathrm{MS}$ data revealed that mass losses were connected to water desorption and $\mathrm{CO}_{2}$ formation [64]. According to DSC signals both processes had exothermic character. The carbon dioxide formation occurs due to the oxidation of carbonaceous species, which have been formed during dry reforming of methane [64].

Fig. 11 shows XRD patterns for the spent catalysts, with typical reflections for metallic nickel $\left(\mathrm{Ni}^{0}\right)$ and periclase mixed oxides $[27,31,38,58]$. These reflections were also observed in the XRD diffractograms for the reduced samples (Fig. 5). However, the XRD patterns for the reduced and spent samples differ in intensities of reflections. Two reflections in the spent catalysts, at ca. $2 \theta=$ $43-46^{\circ}$ overlap, forming one broad diffraction peak. Thus, after reaction, $\mathrm{Ni}$ crystallites size was found to be 5 and $3 \mathrm{~nm}$ for unpromoted and Y-promoted DLHs, respectively.

TEM micrograph analysis revealed that most of the observed carbon deposits are similar to carbon nanotubes (Fig. 12A-C). The observed type of carbon is in line with the temperature of its removal (Fig. 10), showing a peak centered at around $450{ }^{\circ} \mathrm{C}$ [65]. On the right side of the micrographs, the distribution of Ni particles is presented. For HTNi spent catalyst nickel particles were detected in the range of 4-22 nm, with the highest frequency for the size of 10-12 nm. After 
yttrium modification, the range significantly changed to 5-6 nm and 4-5 nm for HTNi-Y0.6 and HTNi-Y1.5, respectively.

XRD and TEM results, indicating the presence of smaller Ni crystallites for the spent materials, suggest re-dispersion of Ni. Such effect was observed before in other studies of double-layered hydroxides. Zr promoted hydrotalcites showed lower nickel particle size after dry reforming of methane in the study performed by Dębek et al. [14] Also, Ru-modified Ni/Mg/Al hydrotalcite, tested in propane reforming, showed ability of reversible reduction and oxidation between metallic nickel and nickel cations [66]. The authors observed sintering of Ni particles after the treatment with a mixture of $\mathrm{H}_{2} / \mathrm{H}_{2} \mathrm{O} / \mathrm{N}_{2}$, followed by re-dispersion due to a partial oxidation step.

Although the decrease in crystallite size is rather unusual, the observation is supported by the research of Nakayama et al. [67]. The authors studied re-dispersion of Ni particles on supported catalysts $\left(\mathrm{Al}_{2} \mathrm{O}_{3}, \mathrm{SiO}_{2}\right)$ during $\mathrm{H}_{2}$ reduction and treatment with oxygen. The scanning microscopy analysis showed sintering of the particles during long time-on-stream experiments in the presence of hydrogen. After testing the materials alternately in $\mathrm{H}_{2}$ reduction and oxidation atmosphere, a redispersion of these particles took place.

Thus, re-dispersion observed in our study may be directly related to the mechanism of the dry reforming reaction. Considering $\mathrm{CO}_{2}$ as a source of oxygen, once it is adsorbed on the catalyst surface, it may be involved in the oxidation of $\mathrm{Ni}^{0}$ sites to $\mathrm{NiO}$ (cp. Figure 3, cp. Figure 9). By adsorption of $\mathrm{H}_{2}$, $\mathrm{CO}$ or perhaps $\mathrm{H}$-species originating from methane molecules activated on the catalyst surface, the Ni-sites are subsequently reduced and thus ready to participate in the DRM reaction. The oxidation of $\mathrm{Ni}$ sites may lead to the regeneration of mixed $\mathrm{NiMg}$ oxides that, in the presence of the reducing atmosphere generated under reaction conditions, might yield $\mathrm{Ni}^{0} \mathrm{species}$ of smaller crystallite size than those present on the catalyst upon reduction pre-treatment prior to 
the catalytic tests. The balance between $\mathrm{Ni}^{0}$ and $\mathrm{NiO}$ in DRM remains a possible hypothesis explaining re-dispersion observed in XRD and TEM analysis.

\section{Conclusions}

Ni-containing $\mathrm{Mg} / \mathrm{Al}$ double-layered hydroxides (DLHs) were promoted with Y. The catalysts were tested in dry reforming of methane in the temperature range of $850-600{ }^{\circ} \mathrm{C}$, and in $10 \mathrm{~h}$ stability tests at $700{ }^{\circ} \mathrm{C}$.

The promotion with yttrium did not result in a separate crystalline phase formation but led to a decrease in the size of Ni crystallites as compared to non-modified Ni-DLHs. Also, a decrease of the reducibility of Ni strongly bonded in a periclase structure and stabilization of weakly bonded $\mathrm{NiO}$ in the HTNi-Y1.5 were observed. The total basicity of the catalyst also decreased, and simultaneously modified the distribution of basic sites, giving an increase in medium and weak basic sites (as a sum of two values) at the expense of strong basic sites.

The best catalytic performance was observed for Ni-based double-layered hydroxides modified with 1.5 wt $\%$ of $\mathrm{Y}$. This, as compared to non-modified Ni-double layered hydroxide, can be ascribed to: (i) smaller Ni crystallite size, (ii) higher specific surface area, and (iii) increased fraction of medium basic sites. Carbon formation was minimized through the control of the Ni crystallite size. Still, some carbon fiber structures could be found, most of them resembling carbon nanotubes and not fishbone-like structures. Among all tested materials in $10 \mathrm{~h}$ experiments, the catalyst modified with $1.5 \mathrm{wt} \%$ yttrium revealed the highest and the most stable values in terms of $\mathrm{CH}_{4}$ and $\mathrm{CO}_{2}$ reaction rates, and the molar ratio of $\mathrm{H}_{2} / \mathrm{CO}$. For the latter, the results were always lower than 1.0, which indicates the occurrence of side reactions. The smaller Ni crystallite sizes for Y-modified catalysts led to suppression of methane decomposition, thus increasing the stability. 
Moreover, possible substitution of $\mathrm{Ni}^{2+}$ ions by $\mathrm{Y}^{3+}$, observed in the HTNi-Y1.5 catalyst, could have contributed to oxygen vacancies formation, further leading to the gasification of carbon formed upon DRM.

The re-dispersion of the metallic nickel during DRM was observed, since $\mathrm{CO}_{2}$ may be considered as a source of oxygen and be involved in the oxidation of $\mathrm{Ni}^{0}$ sites to $\mathrm{NiO}$.

\section{Acknowledgments}

K. Świrk acknowledges the French Embassy in Poland and InnoEnergy PhD School for the financial support during her co-tutelle doctoral studies at Sorbonne Université. K. Świrk would also like to express her gratitude to the KinCat Catalysis Group at NTNU and the Research Council of Norway for the possibility to conduct some of her research during an Erasmus+ traineeship. The authors would like to acknowledge Sandra Casale (Sorbonne Université) for TEM expertise. Part of the work was supported by AGH grant 11.11.210.373.

\section{References}

[1] A.A. Olajire, Valorization of greenhouse carbon dioxide emissions into value-added products by catalytic processes, J. CO2 Util. 3-4 (2013) 74-92. doi:10.1016/j.jcou.2013.10.004.

[2] W. Schakel, G. Oreggioni, B. Singh, A. Strømman, A. Ramírez, Assessing the technoenvironmental performance of $\mathrm{CO}_{2}$ utilization via dry reforming of methane for the production of dimethyl ether, J. CO2 Util. 16 (2016) 138-149. 
doi:10.1016/j.jcou.2016.06.005.

[3] R. Dębek, M. Motak, T. Grzybek, M. Galvez, P. Da Costa, A short review on the catalytic activity of hydrotalcite-derived materials for dry reforming of methane, Catalysts. 7 (2017) 32-57. doi:10.3390/catal7010032.

[4] W. Donphai, T. Witoon, K. Faungnawakij, M. Chareonpanich, Carbon-structure affecting catalytic carbon dioxide reforming of methane reaction over Ni-carbon composites, J. CO2 Util. 16 (2016) 245-256. doi:10.1016/j.jcou.2016.07.011.

[5] M.M. Nair, S. Kaliaguine, F. Kleitz, Nanocast $\mathrm{LaNiO}_{3}$ perovskites as precursors for the preparation of coke-resistant dry reforming catalysts, ACS Catal. 4 (2014) 3837-3846.

[6] T. Margossian, K. Larmier, S.M. Kim, F. Krumeich, C. Müller, C. Copéret, Supported bimetallic NiFe nanoparticles through colloid synthesis for improved dry reforming performance, ACS Catal. 7 (2017) 6942-6948. doi:10.1021/acscatal.7b02091.

[7] X. Xie, T. Otremba, P. Littlewood, R. Schomäcker, A. Thomas, One-pot synthesis of supported, nanocrystalline nickel manganese oxide for dry reforming of methane, ACS Catal. 3 (2013) 224-229. doi:10.1021/cs3003963.

[8] M.S. Fan, A.Z. Abdullah, S. Bhatia, Utilization of greenhouse gases through dry reforming: Screening of nickel-based bimetallic catalysts and kinetic studies, ChemSusChem. 4 (2011) 1643-1653. doi:10.1002/cssc.201100113.

[9] O. Muraza, A. Galadima, A review on coke management during dry reforming of methane, Int. J. Energy Res. 39 (2015) 1196-1216. doi:10.1002/er.

[10] N.D. Charisiou, L. Tzounis, V. Sebastian, S.J. Hinder, M.A. Baker, K. Polychronopoulou, 
M.A. Goula, Investigating the correlation between deactivation and the carbon deposited on the surface of $\mathrm{Ni} / \mathrm{Al}_{2} \mathrm{O}_{3}$ and $\mathrm{Ni} / \mathrm{La}_{2} \mathrm{O}_{3}-\mathrm{Al}_{2} \mathrm{O}_{3}$ catalysts during the biogas reforming reaction, Appl. Surf. Sci. (2018). doi:10.1016/j.apsusc.2018.05.177.

[11] A.I. Tsyganok, M. Inaba, T. Tsunoda, S. Hamakawa, K. Suzuki, T. Hayakawa, Dry reforming of methane over supported noble metals: A novel approach to preparing catalysts, Catal. Commun. 4 (2003) 493-498. doi:10.1016/S1566-7367(03)00130-4.

[12] J.R. Rostrup-Nielsen, Aspects of $\mathrm{CO}_{2}$-reforming of methane, Stud. Surf. Sci. Catal. 81 (1994) 25-41. doi:10.1016/S0167-2991(08)63847-1.

[13] M.J. Hei, H.B. Chen, J. Yi, Y.J. Lin, Y.Z. Lin, G. Wei, D.W. Liao, $\mathrm{CO}_{2}$-reforming of methane on transition metal surfaces, Surf. Sci. 417 (1998) 82-96. doi:10.1016/S00396028(98)00663-3.

[14] R. Dębek, M. Motak, M.E. Galvez, T. Grzybek, P. Da Costa, Influence of Ce/Zr molar ratio on catalytic performance of hydrotalcite-derived catalysts at low temperature $\mathrm{CO}_{2}$ methane reforming, Int. J. Hydrogen Energy. 42 (2017) 1-12. doi:10.1016/j.ijhydene.2016.12.121.

[15] S. Kawi, Y. Kathiraser, J. Ni, U. Oemar, Z. Li, E.T. Saw, Progress in synthesis of highly active and stable nickel-based catalysts for carbon dioxide reforming of methane, ChemSusChem. 8 (2015) 3556-3575. doi:10.1002/cssc.201500390.

[16] Y.H. Hu, E. Ruckenstein, The characterization of a highly effective $\mathrm{NiO} / \mathrm{MgO}$ solid solution catalyst in the $\mathrm{CO}_{2}$ reforming of $\mathrm{CH}_{4}$, Catal. Letters. 43 (1997) 71-77. doi:10.1023/A:1018982304573.

[17] J.-E. Min, Y.-J. Lee, H.-G. Park, C. Zhang, K.-W. Jun, Carbon dioxide reforming of methane 
on $\mathrm{Ni}-\mathrm{MgO}-\mathrm{Al}_{2} \mathrm{O}_{3}$ catalysts prepared by sol-gel method: Effects of $\mathrm{Mg} / \mathrm{Al}$ ratios, $\mathrm{J}$. Ind. Eng. Chem. 26 (2015) 375-383. doi:http://dx.doi.org/10.1016/j.jiec.2014.12.012.

[18] Z. Abdelsadek, M. Sehailia, D. Halliche, V.M. Gonzalez-Delacruz, J.P. Holgado, K. Bachari, A. Caballero, O. Cherifi, In-situ hydrogasification/regeneration of NiAlhydrotalcite derived catalyst in the reaction of $\mathrm{CO}_{2}$ reforming of methane: A versatile approach to catalyst recycling, J. CO2 Util. 14 (2016) 98-105. doi:10.1016/j.jcou.2016.03.004.

[19] F. Cavani, F. Trifirò, A. Vaccari, Hydrotalcite-type anionic clays: Preparation, properties and applications., Catal. Today. 11 (1991) 173-301. doi:10.1016/0920-5861(91)80068-K.

[20] A.I. Tsyganok, K. Suzuki, S. Hamakawa, K. Takehira, T. Hayakawa, Mg-Al layered double hydroxide intercalated with $[\mathrm{Ni}(\mathrm{EDTA})]^{2-}$ chelate as a precursor for an efficient catalyst of methane reforming with carbon dioxide, Catal. Letters. 77 (2001) 75-86. doi:10.1023/A:1012739112430.

[21] Z. Yu, D. Chen, M. Rønning, T. Vrålstad, E. Ochoa-Fernández, A. Holmen, Large-scale synthesis of carbon nanofibers on Ni-Fe-Al hydrotalcite derived catalysts. I. Preparation and characterization of the Ni-Fe-Al hydrotalcites and their derived catalysts, Appl. Catal. A Gen. 338 (2008) 136-146. doi:10.1016/j.apcata.2008.01.003.

[22] B.K. Kim, G.H. Gwak, T. Okada, J.M. Oh, Effect of particle size and local disorder on specific surface area of layered double hydroxides upon calcination-reconstruction, J. Solid State Chem. 263 (2018) 60-64. doi:10.1016/j.jssc.2018.03.041.

[23] O.D. Pavel, D. Tichit, I.C. Marcu, Acido-basic and catalytic properties of transition-metal 
containing Mg-Al hydrotalcites and their corresponding mixed oxides, Appl. Clay Sci. 61 (2012) 52-58. doi:10.1016/j.clay.2012.03.006.

[24] Y. Zhu, S. Zhang, B. Chen, Z. Zhang, C. Shi, Effect of Mg/Al ratio of NiMgAl mixed oxide catalyst derived from hydrotalcite for carbon dioxide reforming of methane, Catal. Today. 264 (2016) 163-170. doi:10.1016/j.cattod.2015.07.037.

[25] R. Dębek, M.E. Galvez, F. Launay, M. Motak, T. Grzybek, P. Da Costa, Low temperature dry methane reforming over $\mathrm{Ce}, \mathrm{Zr}$ and $\mathrm{CeZr}$ promoted $\mathrm{Ni}-\mathrm{Mg}-\mathrm{Al}$ hydrotalcite-derived catalysts, Int. J. Hydrogen Energy. 41 (2016) 11616-11623. doi:10.1016/j.jhydene.2016.02.074.

[26] R. Dębek, M. Motak, D. Duraczyska, F. Launay, M.E. Galvez, T. Grzybek, P. Da Costa, Methane dry reforming over hydrotalcite-derived $\mathrm{Ni}-\mathrm{Mg}-\mathrm{Al}$ mixed oxides: the influence of Ni content on catalytic activity, selectivity and stability, Catal. Sci. Technol. 6 (2016) 67056715. doi:10.1039/C6CY00906A.

[27] H. Liu, D. Wierzbicki, R. Debek, M. Motak, T. Grzybek, P. Da Costa, M.E. Gálvez, Lapromoted Ni-hydrotalcite-derived catalysts for dry reforming of methane at low temperatures, Fuel. 182 (2016) 8-16. doi:10.1016/j.fuel.2016.05.073.

[28] R. Dębek, K. Zubek, M. Motak, M.E. Galvez, P. Da Costa, T. Grzybek, Ni-Al hydrotalcitelike material as the catalyst precursors for the dry reforming of methane at low temperature, Comptes Rendus Chim. 18 (2015) 1205-1210. doi:10.1016/j.crci.2015.04.005.

[29] A. Bhattacharyya, V.W. Chang, D.J. Schumacher, $\mathrm{CO}_{2}$ reforming of methane to syngas I: Evaluation of hydrotalcite clay-derived catalysts, Appl. Clay Sci. 13 (1998) 317-328. 
doi:10.1016/S0169-1317(98)00030-1.

[30] K. Mette, S. Kühl, A. Tarasov, M.G. Willinger, J. Kröhnert, S. Wrabetz, A. Trunschke, M. Scherzer, F. Girgsdies, H. Düdder, K. Kähler, K.F. Ortega, M. Muhler, R. Schlögl, M. Behrens, T. Lunkenbein, High-temperature stable Ni nanoparticles for the dry reforming of methane, ACS Catal. 6 (2016) 7238-7248. doi:10.1021/acscatal.6b01683.

[31] R. Dębek, M. Radlik, M. Motak, M.E. Galvez, W. Turek, P. Da Costa, T. Grzybek, Nicontaining Ce-promoted hydrotalcite derived materials as catalysts for methane reforming with carbon dioxide at low temperature - On the effect of basicity, Catal. Today. 257 (2015) 59-65. doi:10.1016/j.cattod.2015.03.017.

[32] O.A. Bereketidou, M.A. Goula, Biogas reforming for syngas production over nickel supported on ceria-alumina catalysts, Catal. Today. 195 (2012) 93-100. doi:10.1016/j.cattod.2012.07.006.

[33] J.M. Francis, W.H. Whitlow, The effect of yttrium on the high temperature oxidation resistance of some Fe-Cr base alloys in carbon dioxide, Corros. Sci. 5 (1965) 701-710. doi:10.1016/S0010-938X(65)80026-9.

[34] Y. Chen, B. Liaw, C. Kao, J. Kuo, Yttria-stabilized zirconia supported platinum catalysts (Pt /YSZs) for $\mathrm{CH}_{4} / \mathrm{CO}_{2}$ reforming, Appl. Catal. 217 (2001) 23-31.

[35] J.D.A. Bellido, E.M. Assaf, Effect of the $\mathrm{Y}_{2} \mathrm{O}_{3}-\mathrm{ZrO}_{2}$ support composition on nickel catalyst evaluated in dry reforming of methane, Appl. Catal. A Gen. 352 (2009) 179-187. doi:10.1016/j.apcata.2008.10.002.

[36] B. Li, S. Zhang, Methane reforming with $\mathrm{CO}_{2}$ using nickel catalysts supported on yttria- 
doped SBA-15 mesoporous materials via sol-gel process, Int. J. Hydrogen Energy. 38 (2013) 14250-14260. doi:10.1016/j.ijhydene.2013.08.105.

[37] Q. Wu, J. Chen, J.Zhang, Effect of yttrium and praseodymium on properties of $\mathrm{Ce}_{0.75} \mathrm{Zr}_{0.25} \mathrm{O}_{2}$ solid solution for $\mathrm{CH}_{4}-\mathrm{CO}_{2}$ reforming, Fuel Process. Technol. 89 (2008) 993-999. doi:10.1016/j.fuproc.2008.03.006.

[38] K. Świrk, M.E. Gálvez, M. Motak, T. Grzybek, M. Rønning, P. Da Costa, Syngas production from dry methane reforming over yttrium-promoted nickel-KIT-6 catalysts, Int. J. Hydrogen Energy. (2018) 1-13. doi:10.1016/j.ijhydene.2018.02.164.

[39] Z. Taherian, M. Yousefpour, M. Tajally, B. Khoshandam, A comparative study of $\mathrm{ZrO}_{2}$, $\mathrm{Y}_{2} \mathrm{O}_{3}$ and $\mathrm{Sm}_{2} \mathrm{O}_{3}$ promoted Ni/SBA-15 catalysts for evaluation of $\mathrm{CO}_{2} /$ methane reforming performance, Int. J. Hydrogen Energy. $42 \quad$ (2017) 16408-16420. doi:10.1016/j.ijhydene.2017.05.095.

[40] B. Li, W. Su, X. Wang, X. Wang, Alumina supported Ni and Co catalysts modified by $\mathrm{Y}_{2} \mathrm{O}_{3}$ via different impregnation strategies: Comparative analysis on structural properties and catalytic performance in methane reforming with $\mathrm{CO}_{2}$, Int. J. Hydrogen Energy. 41 (2016) 14732-14746. doi:10.1016/j.ijhydene.2016.06.219.

[41] X. Huang, G. Xue, C. Wang, N. Zhao, N. Sun, W. Wei, Y. Sun, Highly stable mesoporous $\mathrm{NiO}-\mathrm{Y}_{2} \mathrm{O}_{3}-\mathrm{Al}_{2} \mathrm{O}_{3}$ catalysts for $\mathrm{CO}_{2}$ reforming of methane: effect of $\mathrm{Ni}$ embedding and $\mathrm{Y}_{2} \mathrm{O}_{3}$ promotion, Catal. Sci. Technol. 6 (2016) 449-459. doi:10.1039/C5CY01171J.

[42] O.D. Pavel, B. Cojocaru, E. Angelescu, V.I. Pârvulescu, The activity of yttrium-modified $\mathrm{Mg}, \mathrm{Al}$ hydrotalcites in the epoxidation of styrene with hydrogen peroxide, Appl. Catal. A 
Gen. 403 (2011) 83-90. doi:10.1016/j.apcata.2011.06.017.

[43] E. Angelescu, O.D. Pavel, M. Che, R. Bîrjega, G. Constentin, Cyanoethylation of ethanol on Mg-Al hydrotalcites promoted by $\mathrm{Y}^{3+}$ and $\mathrm{La}^{3+}$, Catal. Commun. 5 (2004) 647-651. doi:10.1016/j.catcom.2004.07.016.

[44] Z. Wang, P. Fongarland, G. Lu, N. Essayem, Reconstructed La-, Y-, Ce-modified MgAlhydrotalcite as a solid base catalyst for aldol condensation: Investigation of water tolerance, J. Catal. 318 (2014) 108-118. doi:10.1016/j.jcat.2014.07.006.

[45] P. Cao, S. Adegbite, H. Zhao, E. Lester, T. Wu, Tuning dry reforming of methane for F-T syntheses: A thermodynamic approach, Appl. Energy. (2017) http://10.1016/j.apenergy.2017.08.007. doi:10.1016/j.apenergy.2017.08.007.

[46] W.-H. Chen, C.-L. Hsu, S.-W. Du, Thermodynamic analysis of the partial oxidation of coke oven gas for indirect reduction of iron oxides in a blast furnace, Energy. 86 (2015) 758-771. doi:10.1016/j.energy.2015.04.087.

[47] M.S. Challiwala, M.M. Ghouri, P. Linke, M.M. El-Halwagi, N.O. Elbashir, A combined thermo-kinetic analysis of various methane reforming technologies: Comparison with dry reforming, J. CO2 Util. 17 (2017) 99-111. doi:10.1016/j.jcou.2016.11.008.

[48] A.C.D. Freitas, R. Guirardello, Thermodynamic analysis of methane reforming with $\mathrm{CO}_{2}$, $\mathrm{CO}_{2}+\mathrm{H}_{2} \mathrm{O}, \mathrm{CO}_{2}+\mathrm{O}_{2}$ and $\mathrm{CO}_{2}+$ air for hydrogen and synthesis gas production, J. CO2 Util. 7 (2014) 30-38. doi:10.1016/j.jcou.2014.06.004.

[49] M.K. Nikoo, N.A.S. Amin, Thermodynamic analysis of carbon dioxide reforming of methane in view of solid carbon formation, Fuel Process. Technol. 92 (2011) 678-691. 
doi:10.1016/j.fuproc.2010.11.027.

[50] D. Pakhare, J. Spivey, A review of dry $\left(\mathrm{CO}_{2}\right)$ reforming of methane over noble metal catalysts, Chem. Soc. Rev. 43 (2014) 7813-7837. doi:10.1039/C3CS60395D.

[51] A.E. Abasaeed, A.S. Al-Fatesh, M.A. Naeem, A.A. Ibrahim, A.H. Fakeeha, Catalytic performance of $\mathrm{CeO}_{2}$ and $\mathrm{ZrO}_{2}$ supported Co catalysts for hydrogen production via dry reforming of methane, Int. J. Hydrogen Energy. 40 (2015) 6818-6826. doi:10.1016/j.ijhydene.2015.03.152.

[52] F. Kovanda, D. Koloušek, Z. Cílová, V. Hulínský, Crystallization of synthetic hydrotalcite under hydrothermal conditions, Appl. Clay Sci. 28 (2005) 101-109. doi:10.1016/j.clay.2004.01.009.

[53] J.F. Li, C. Xia, C.T. Au, B.S. Liu, $\mathrm{Y}_{2} \mathrm{O}_{3}$-promoted NiO/SBA-15 catalysts highly active for $\mathrm{CO}_{2} / \mathrm{CH}_{4}$ reforming, Int. J. Hydrogen Energy. 39 (2014) 10927-10940. doi:10.1016/j.ijhydene.2014.05.021.

[54] J.M. García-García, M.E. Pérez-Bernal, R.J. Ruano-Casero, V. Rives, Chromium and yttrium-doped magnesium aluminum oxides prepared from layered double hydroxides, Solid State Sci. 9 (2007) 1115-1125. doi:10.1016/j.solidstatesciences.2007.07.029.

[55] J.M. Fernández, C. Barriga, M.A. Ulibarri, F.M. Labajos, V. Rives, New hydrotalcite-like compounds containing yttrium, Chem. Mater. 9 (1997) 312-318. doi:10.1021/cm9603720.

[56] M. Broda, A.M. Kierzkowska, D. Baudouin, Q. Imtiaz, C. Copéret, C.R. Müller, Sorbentenhanced methane reforming over a Ni-Ca-based, bifunctional catalyst sorbent, ACS Catal. 2 (2012) 1635-1646. doi:10.1021/cs300247g. 
[57] R. Dębek, M. Motak, M.E. Galvez, T. Grzybek, P. Da Costa, Promotion effect of zirconia on $\mathrm{Mg}(\mathrm{Ni}, \mathrm{Al}) \mathrm{O}$ mixed oxides derived from hydrotalcites in $\mathrm{CO}_{2}$ methane reforming, Appl. Catal. B Environ. (2018) 36-46. doi:10.1016/j.apcatb.2017.06.024.

[58] H. Shang, K. Pan, L.Zhang, B. Zhang, X. Xiang, Enhanced activity of supported Ni catalysts promoted by Pt for rapid reduction of aromatic nitro compounds, Nanomaterials. 6 (2016) 103-117. doi:10.3390/nano6060103.

[59] D.G. Mustard, C.H. Bartholomew, Determination of metal crystallite supported size and morphology supported nickel catalysts, J. Catal. 67 (1981) 186-206. doi:10.1016/00219517(81)90271-2.

[60] N.A.K. Aramouni, J.G. Touma, B.A. Tarboush, J. Zeaiter, M.N. Ahmad, Catalyst design for dry reforming of methane: Analysis review, Renew. Sustain. Energy Rev. 82 (2018) 25702585. doi:10.1016/j.rser.2017.09.076.

[61] H. Seo, Recent scientific progress on developing supported $\mathrm{Ni}$ catalysts for dry $\left(\mathrm{CO}_{2}\right)$ reforming of methane, Catalysts. 8 (2018) 110. doi:10.3390/catal8030110.

[62] S. Daneshmand-Jahromi, M. Reza Rahimpour, M. Meshksar, A. Hafiz, Hydrogen Production from cyclic chemical looping steam methane reforming over yttrium promoted Ni/SBA-16 oxygen carrier, Catalysts. 7 (2017) 286. doi:10.3390/catal7100286.

[63] A.A. Lytkina, N. V. Orekhova, M.M. Ermilova, A.B. Yaroslavtsev, The influence of the support composition and structure $\left(\mathrm{M}_{\mathrm{X}} \mathrm{Zr}_{1-\mathrm{X}} \mathrm{O}_{2-\delta}\right)$ of bimetallic catalysts on the activity in methanol steam reforming, Int. J. Hydrogen Energy. 43 (2018) 198-207. doi:10.1016/j.jjhydene.2017.10.182. 
[64] A.I. Tsyganok, T. Tsunoda, S. Hamakawa, K. Suzuki, K. Takehira, T. Hayakawa, Dry reforming of methane over catalysts derived from nickel-containing Mg-Al layered double hydroxides, J. Catal. 213 (2003) 191-203. doi:10.1016/S0021-9517(02)00047-7.

[65] G. de Souza, N.R. Marcilio, O.W. Perez-Lopez, Dry reforming of methane at moderate temperatures over modified Co-Al Co-precipitated catalysts, Mater. Res. 17 (2014) 10471055. doi:10.1590/1516-1439.269614.

[66] D. Li, K. Nishida, Y. Zhan, T. Shishido, Y. Oumi, T. Sano, K. Takehira, Sustainable Rudoped Ni catalyst derived from hydrotalcite in propane reforming, Appl. Clay Sci. 43 (2009) 49-56. doi:10.1016/j.clay.2008.07.014.

[67] T. Nakayama, M. Arai, Y. Nishiyama, Dispersion of nickel particles supported on alumina and silica in oxygen and hydrogen, J. Catal. 87 (1984) 108-115. doi:10.1016/00219517(84)90173-8 . 


\section{Figure captions:}

Fig. 1. Equilibrium amounts for gaseous components and coke in the dry reforming of methane process $\left(\mathrm{CH}_{4} / \mathrm{CO}_{2} / \mathrm{Ar}=1 / 1 / 8, \mathrm{p}=1\right.$ bar $)$.

Fig. 2. Equilibrium conversions of $\mathrm{CH}_{4}, \mathrm{CO}_{2}$, and $\mathrm{H}_{2} / \mathrm{CO}$ molar ratio in the dry reforming of methane process $\left(\mathrm{CH}_{4} / \mathrm{CO}_{2} / \mathrm{Ar}=1 / 1 / 8, \mathrm{p}=1\right.$ bar $)$.

Fig. 3. Temperature-programmed reduction $\left(\mathrm{TPR}-\mathrm{H}_{2}\right)$ profiles for the reduced samples.

Fig. 4. Temperature-programmed desorption $\left(\mathrm{TPD}-\mathrm{CO}_{2}\right)$ profiles for the reduced samples.

Fig. 5. XRD patterns for reduced samples HTNi, HTNi-Y0.6 and HTNi-Y1.5.

Fig. 6. TEM images of HTNi reduced (A), HTNi-Y0.6 reduced (B), HTNi-1.5 reduced (C).

Fig. 7. Activity results of $\mathrm{HTNi}-\mathrm{Y}$ catalysts in the temperature range of 850 to $600{ }^{\circ} \mathrm{C}: \mathrm{CH}_{4}$ conversion (A), $\mathrm{CO}_{2}$ conversion (B), and $\mathrm{H}_{2} / \mathrm{CO}$ molar ratio (C) versus temperature in DRM process $\left(\mathrm{CH}_{4} / \mathrm{CO}_{2} / \mathrm{Ar}=1 / 1 / 8, \mathrm{GHSV}=20,000 \mathrm{~h}^{-1}\right)$. The solid line represents the thermodynamic equilibrium limit.

Fig. 8. Stability results for $\mathrm{HTNi}$ Y catalysts at $700{ }^{\circ} \mathrm{C}$ for $10 \mathrm{~h}: \mathrm{CH}_{4}$ conversion (A), $\mathrm{CO}_{2}$ conversion (B), and $\mathrm{H}_{2} / \mathrm{CO}$ molar ratio $(\mathrm{C})$, versus time on stream in DRM $\left(\mathrm{CH}_{4} / \mathrm{CO}_{2} / \mathrm{Ar}=1 / 1 / 8\right.$, GHSV $\left.=20,000 \mathrm{~h}^{-1}\right)$. The solid line represents the thermodynamic equilibrium limit.

Fig. 9. Temperature-programmed reduction $\left(\mathrm{TPR}-\mathrm{H}_{2}\right)$ profiles for the spent catalysts.

Fig. 10. TGA/DSC-MS curves of spent HTNi-Y catalysts. Decomposition of the samples in air $\left(100 \mathrm{ml} / \mathrm{min}\right.$, heat rate $\left.10^{\circ} \mathrm{C} / \mathrm{min}\right)$.

Fig. 11. XRD patterns for spent samples HTNi, HTNi-Y0.6 and HTNi-Y1.5. 
Fig. 12. TEM images of HTNi spent (A), HTNi-Y0.6 spent (B), HTNi-1.5 spent (C), and histograms of Ni particle size distribution. 


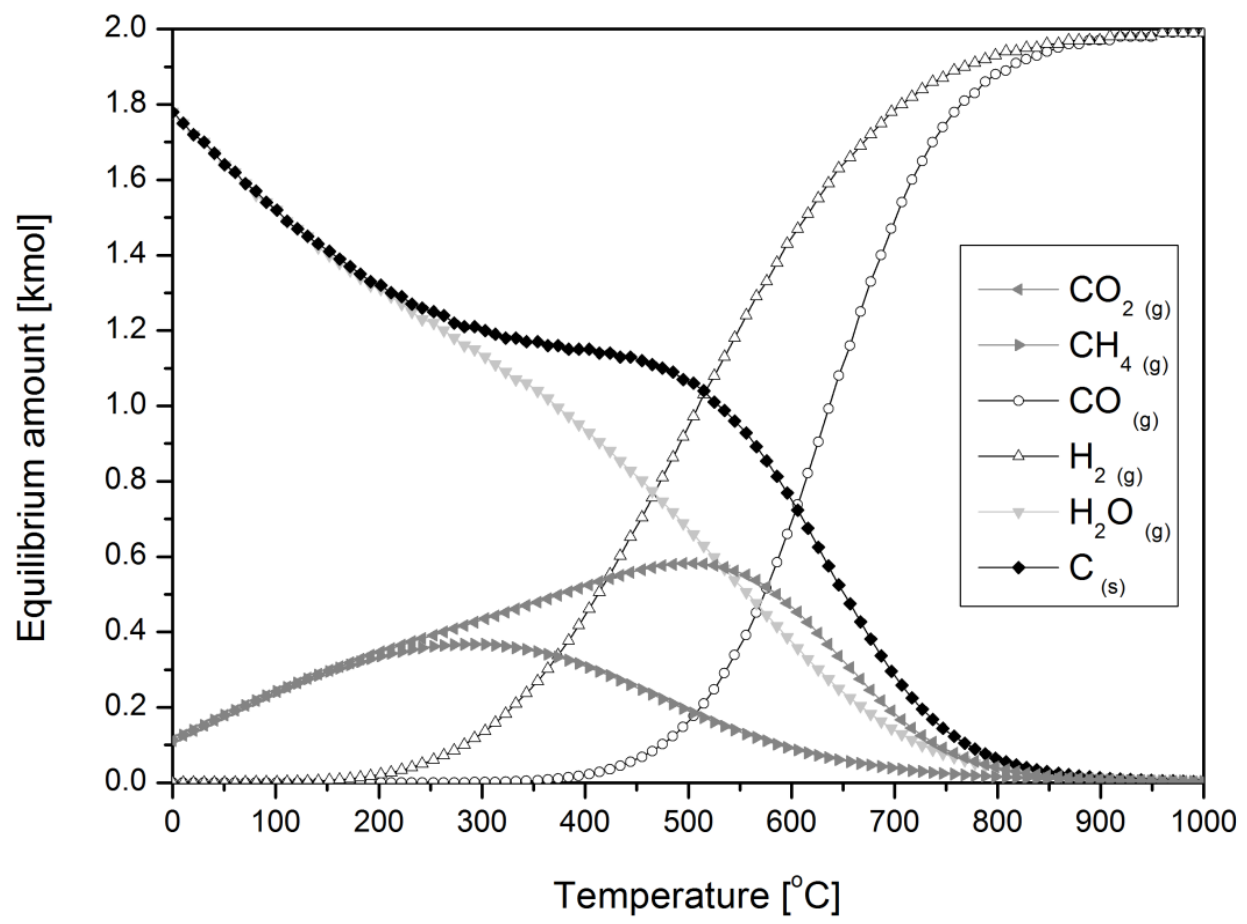

Fig. 1. Equilibrium amounts for gaseous components and coke in the dry reforming of methane process $\left(\mathrm{CH}_{4} / \mathrm{CO}_{2} / \mathrm{Ar}=1 / 1 / 8, \mathrm{p}=1\right.$ bar $)$. 


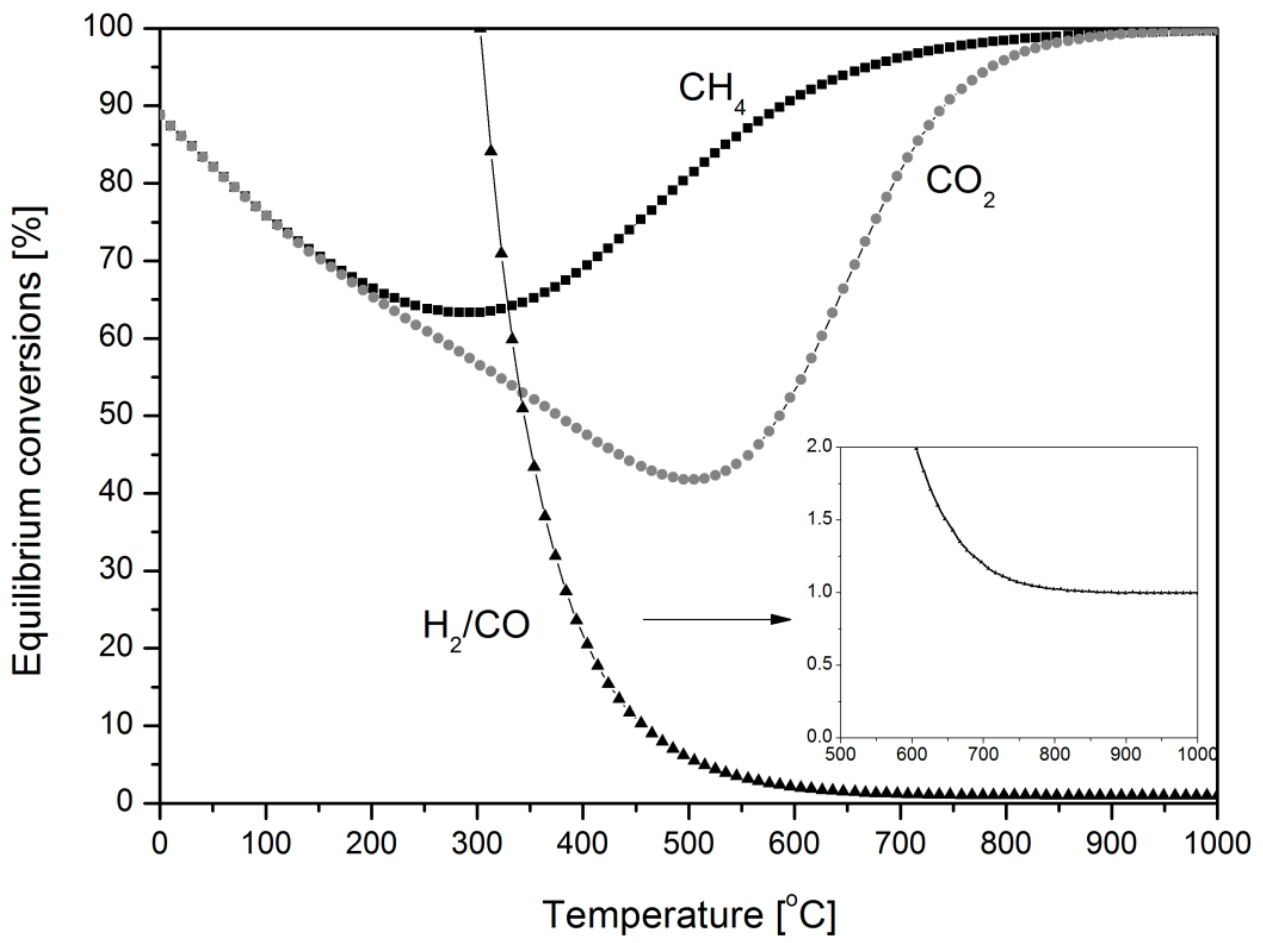

Fig. 2. Equilibrium conversions of $\mathrm{CH}_{4}, \mathrm{CO}_{2}$, and $\mathrm{H}_{2} / \mathrm{CO}$ molar ratio in the dry reforming of methane process $\left(\mathrm{CH}_{4} / \mathrm{CO}_{2} / \mathrm{Ar}=1 / 1 / 8, \mathrm{p}=1 \mathrm{bar}\right)$. 


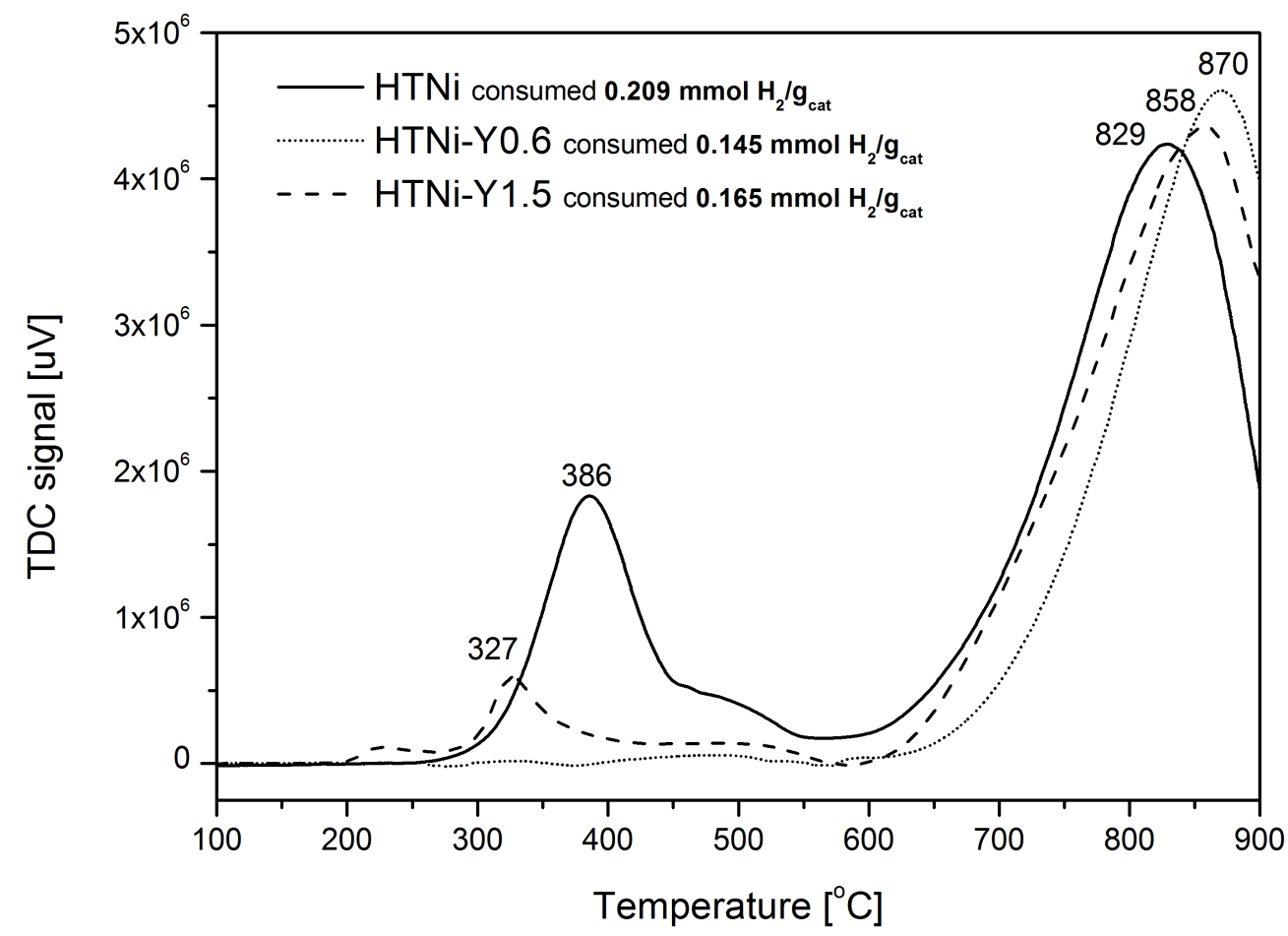

Fig. 3. Temperature-programmed reduction (TPR- $\left.\mathrm{H}_{2}\right)$ profiles for the reduced samples. 


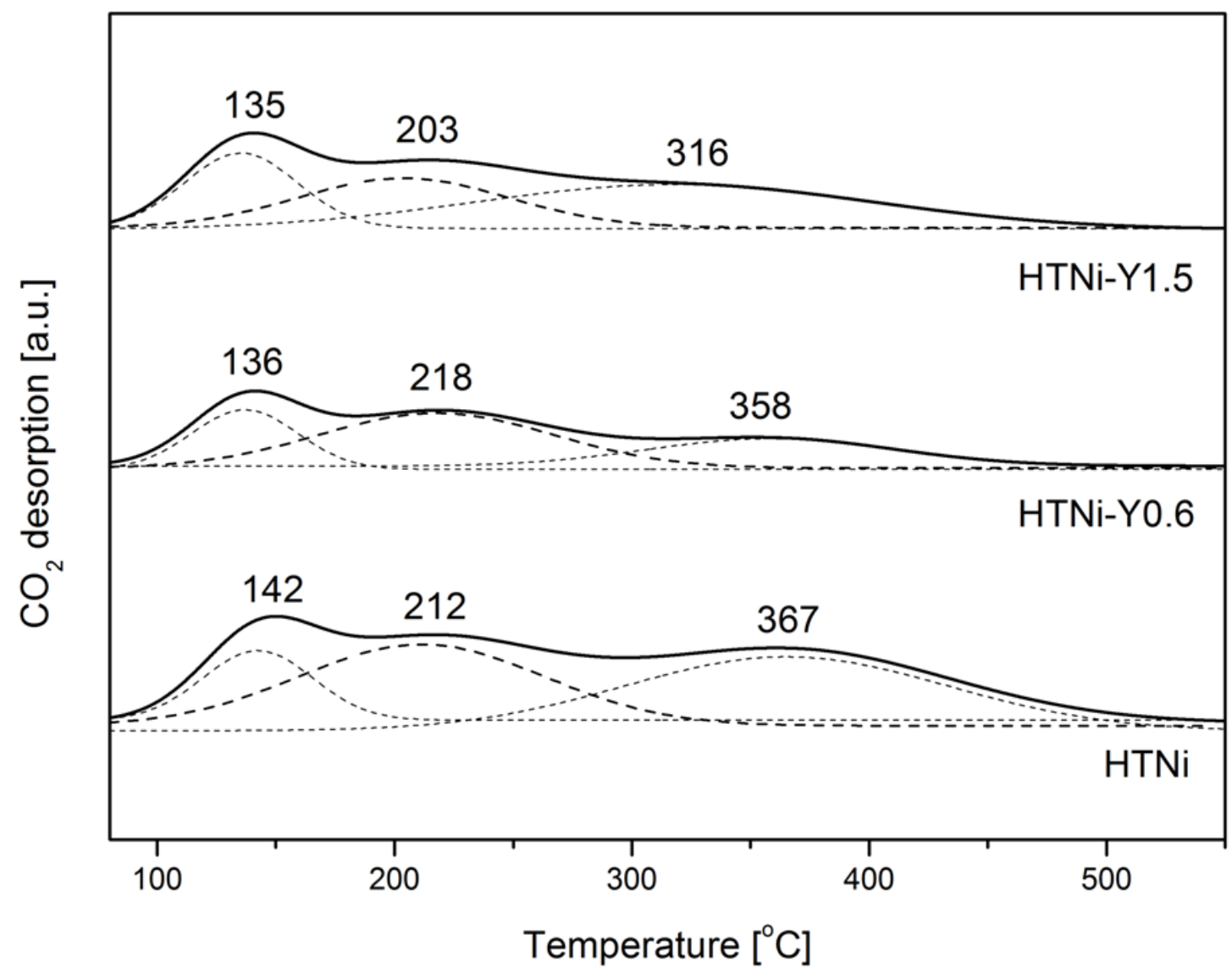

Fig. 4. Temperature-programmed desorption (TPD- $\left.\mathrm{CO}_{2}\right)$ profiles for the reduced samples. 


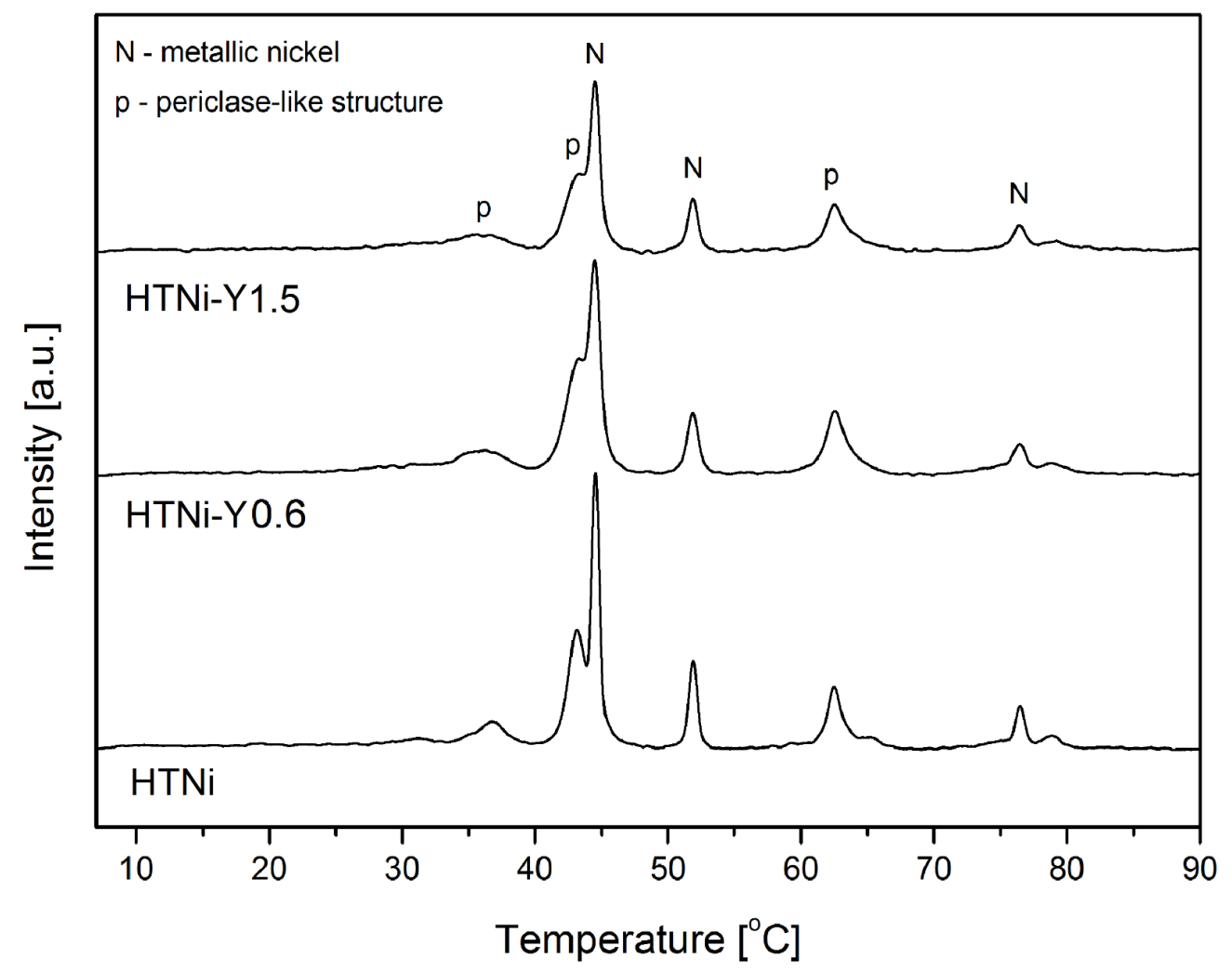

Fig. 5. XRD patterns for reduced samples HTNi, HTNi-Y0.6 and HTNi-Y1.5. 


\section{A) HTNi reduced}
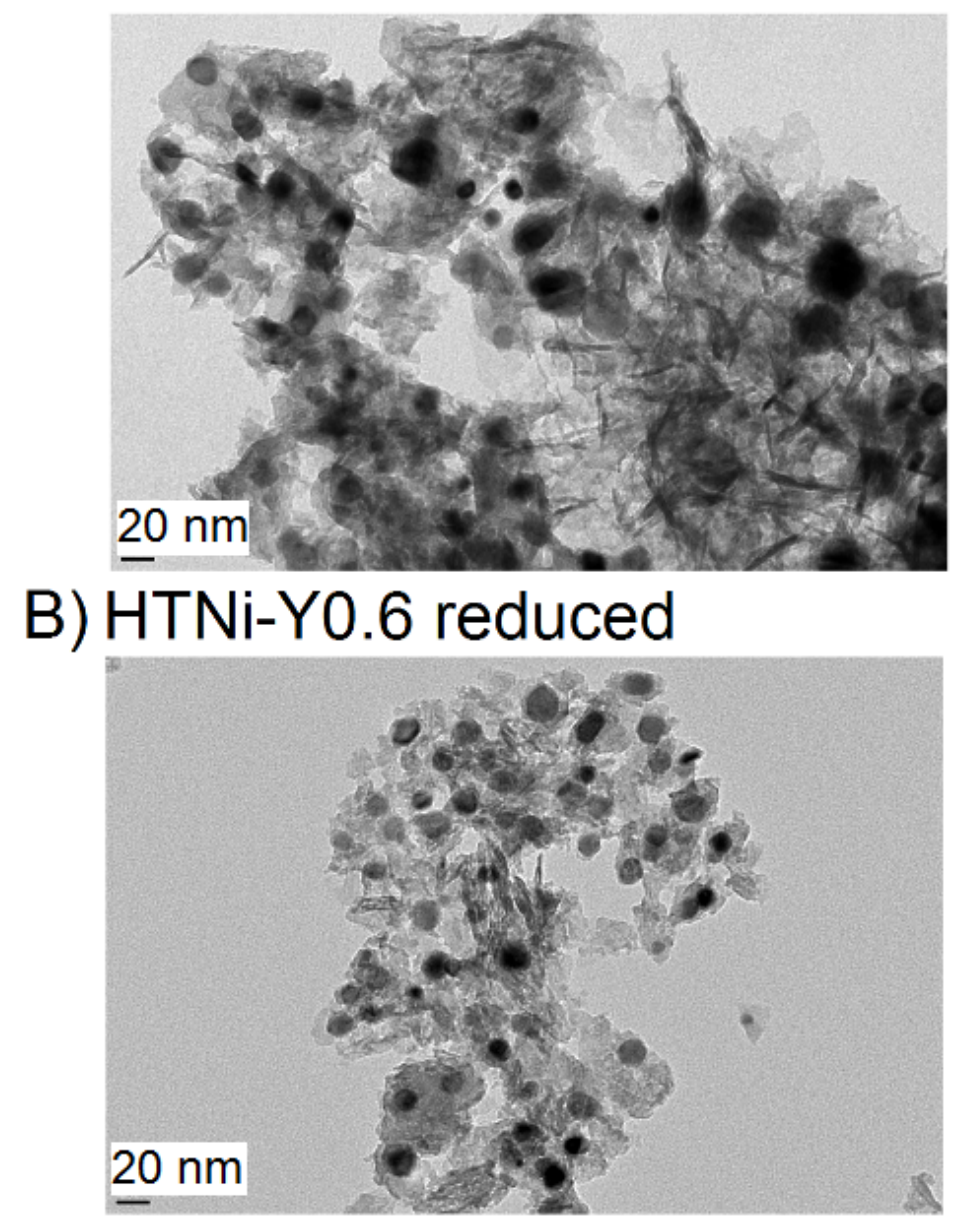

\section{C) HTNi-Y1.5 reduced}

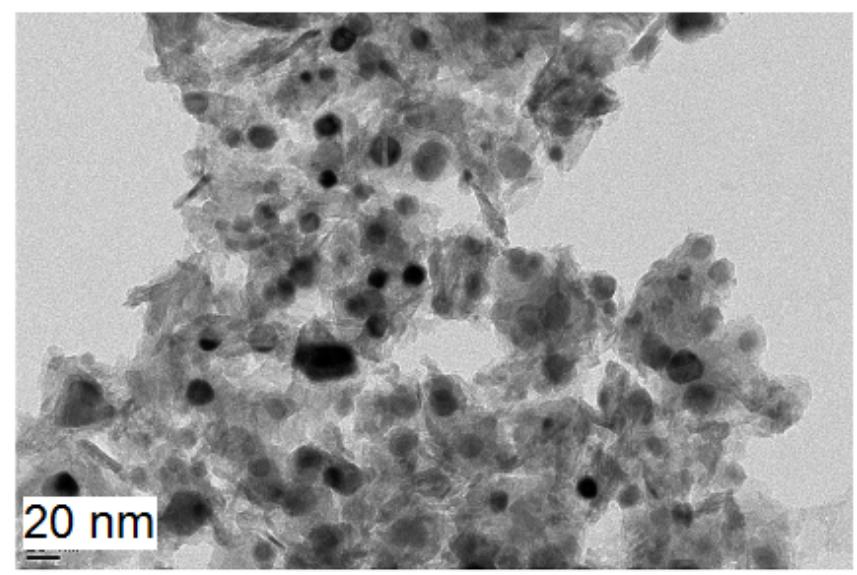

Fig. 6. TEM images of HTNi reduced (A), HTNi-Y0.6 reduced (B), HTNi-1.5 reduced (C). 
A)

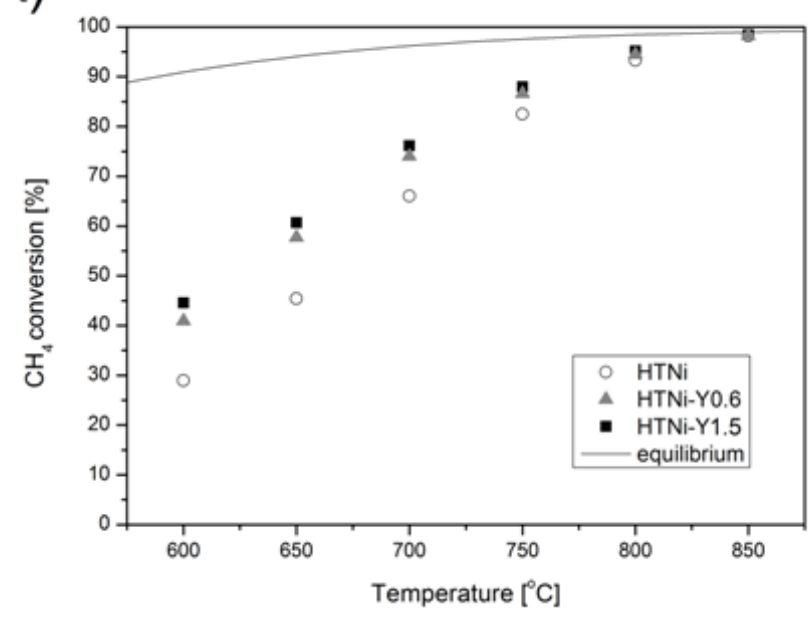

B)

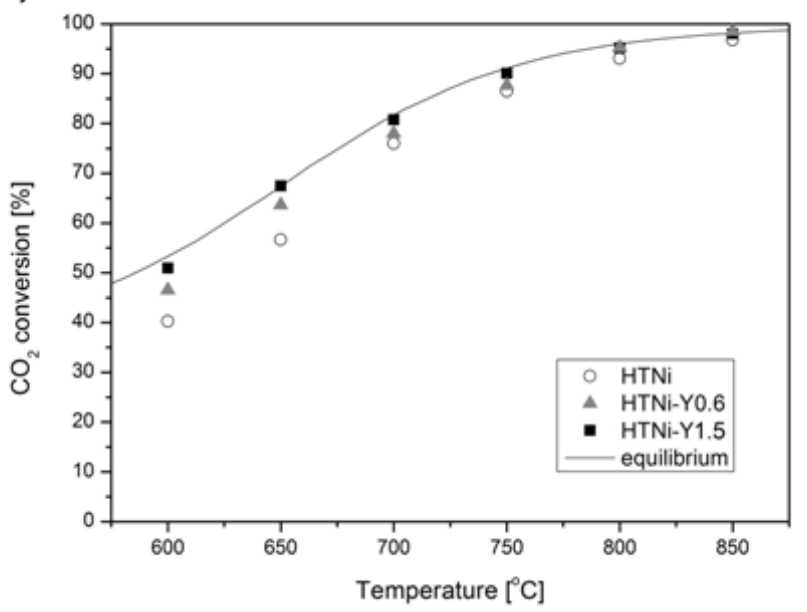

C)

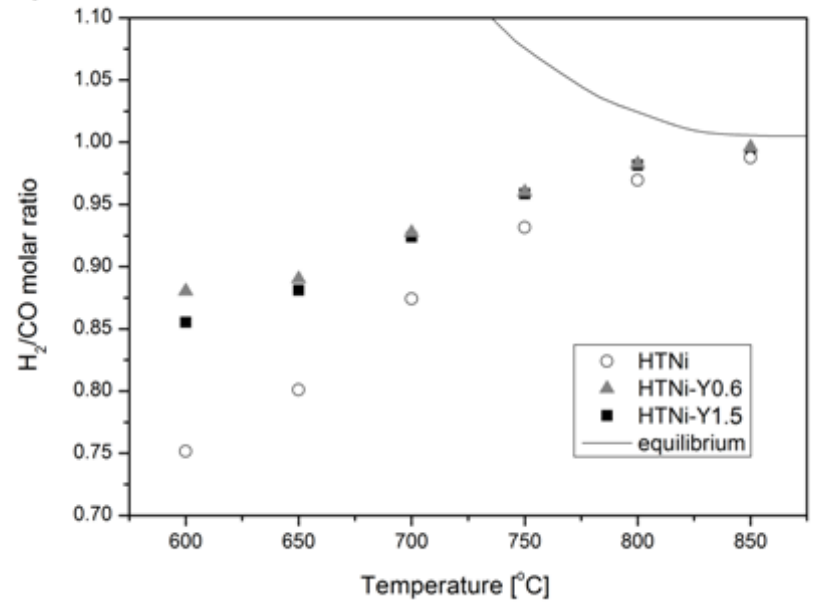

Fig. 7. Activity results of HTNi-Y catalysts in the temperature range of 850 to $600{ }^{\circ} \mathrm{C}: \mathrm{CH}_{4}$ conversion (A), $\mathrm{CO}_{2}$ conversion (B), and $\mathrm{H}_{2} / \mathrm{CO}$ molar ratio (C) versus temperature in DRM 
process $\left(\mathrm{CH}_{4} / \mathrm{CO}_{2} / \mathrm{Ar}=1 / 1 / 8, \mathrm{GHSV}=20,000 \mathrm{~h}^{-1}\right)$. The solid line represents the thermodynamic equilibrium limit.

A)

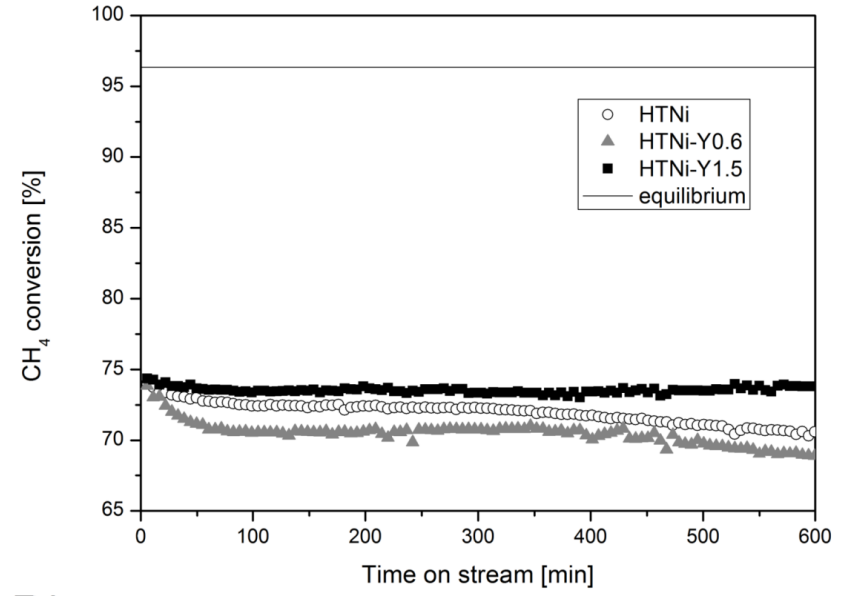

B)

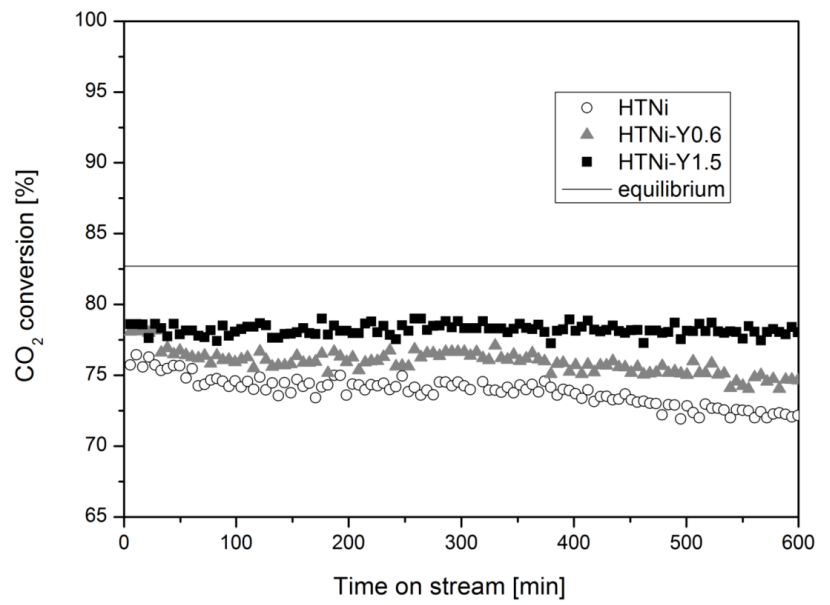

C)

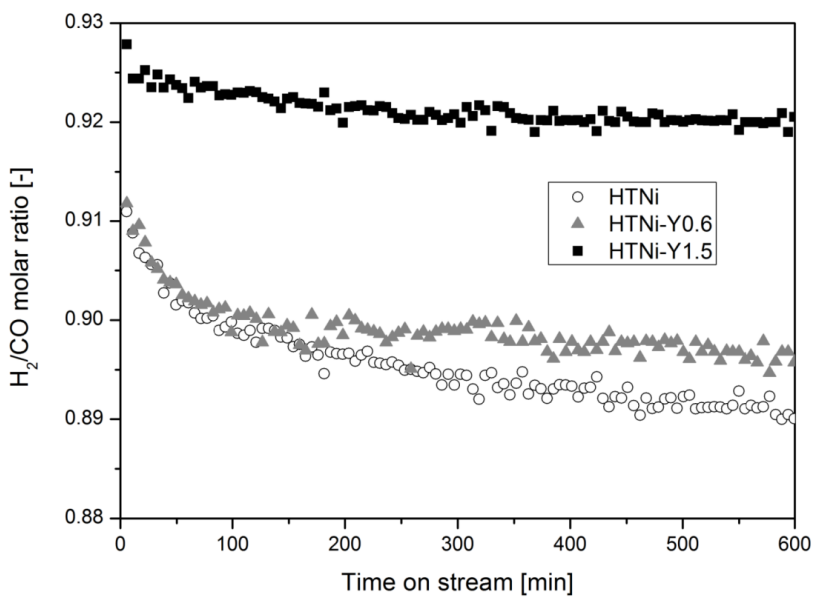


Fig. 8. Stability results for $\mathrm{HTNi}-\mathrm{Y}$ catalysts at $700{ }^{\circ} \mathrm{C}$ for $10 \mathrm{~h}: \mathrm{CH}_{4}$ conversion (A), $\mathrm{CO}_{2}$ conversion (B), and $\mathrm{H}_{2} / \mathrm{CO}$ molar ratio $(\mathrm{C})$, versus time on stream in DRM $\left(\mathrm{CH}_{4} / \mathrm{CO}_{2} / \mathrm{Ar}=1 / 1 / 8\right.$, GHSV $\left.=20,000 \mathrm{~h}^{-1}\right)$. The solid line represents the thermodynamic equilibrium limit.

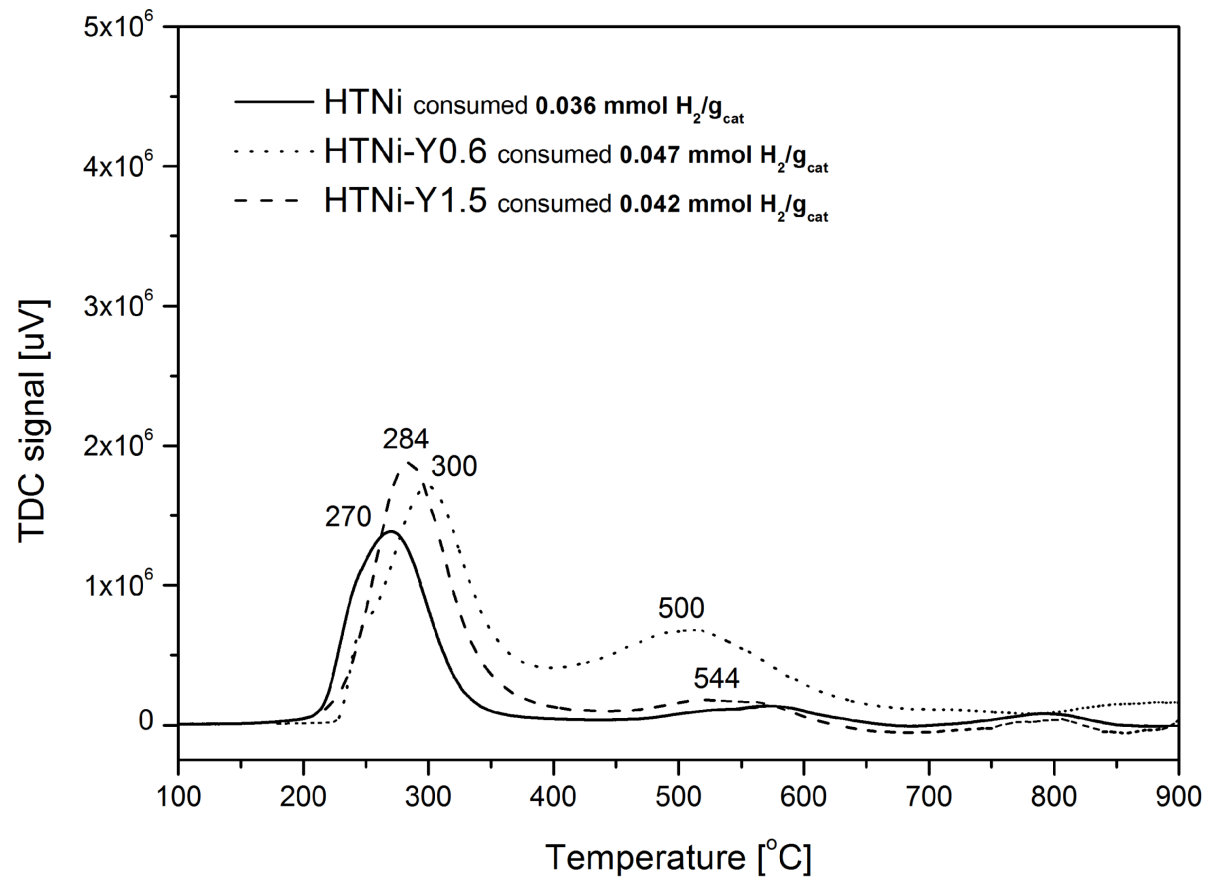

Fig. 9. Temperature-programmed reduction $\left(\mathrm{TPR}-\mathrm{H}_{2}\right)$ profiles for the spent catalysts. 
A)

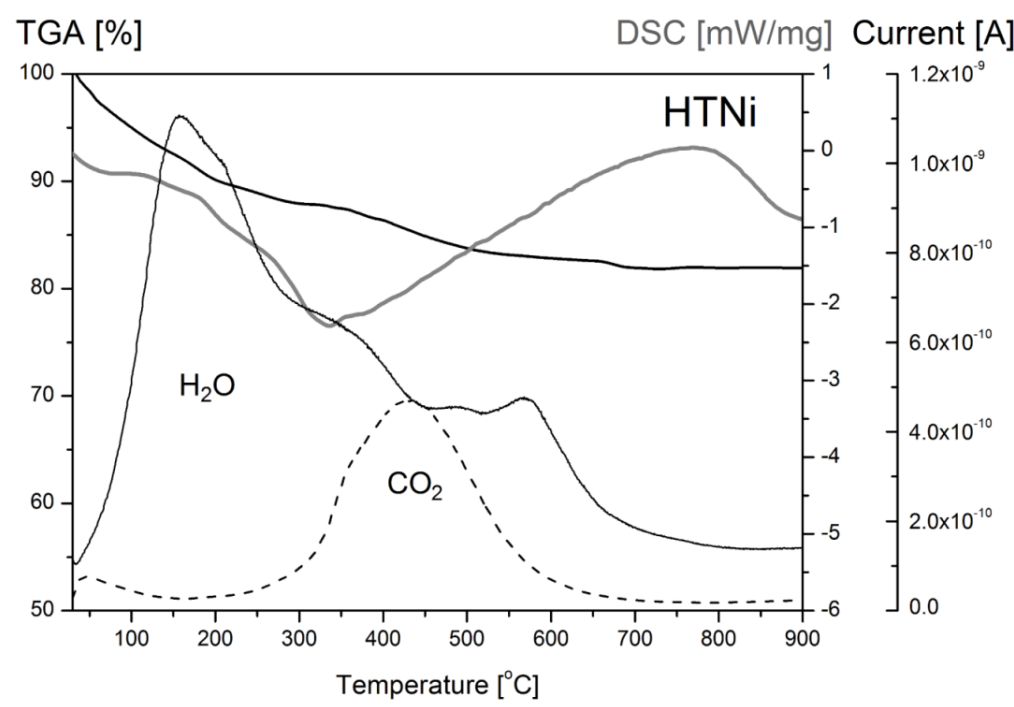

B)

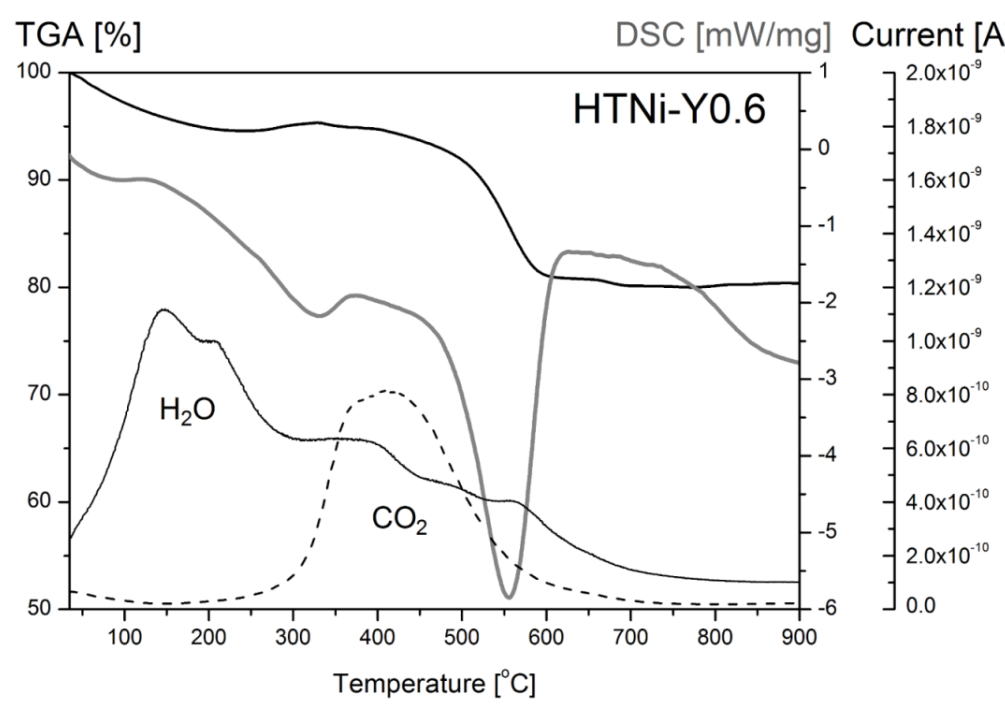

C)

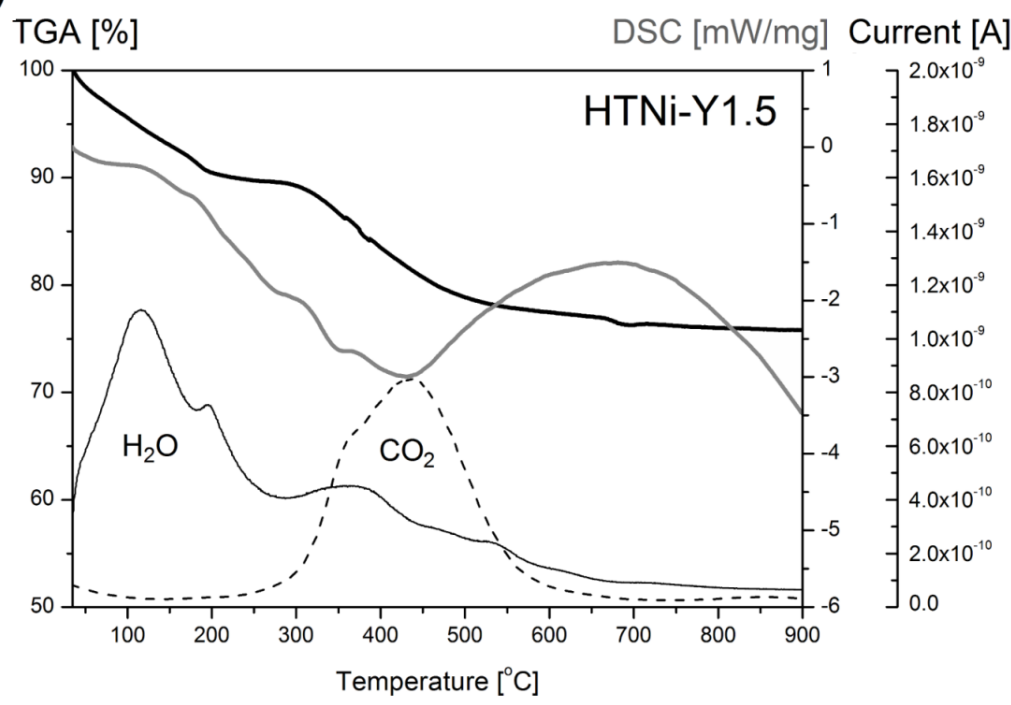


Fig. 10. TGA/DSC-MS curves of spent HTNi-Y catalysts. Decomposition of the samples in air $\left(100 \mathrm{ml} / \mathrm{min}\right.$, heat rate $\left.10^{\circ} \mathrm{C} / \mathrm{min}\right)$.

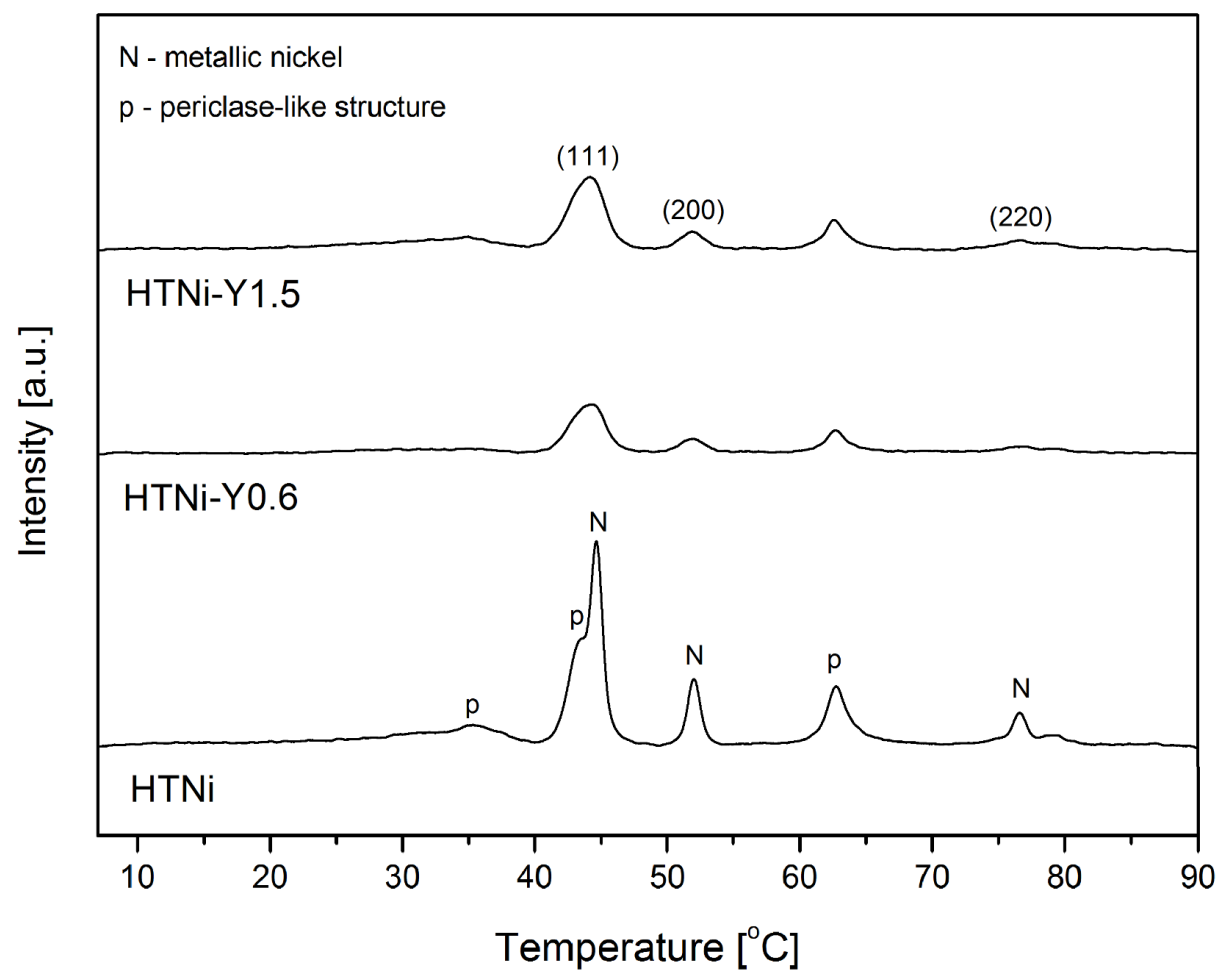

Fig. 11. XRD patterns for spent samples HTNi, HTNi-Y0.6 and HTNi-Y1.5. 


\section{A) HTNi spent}
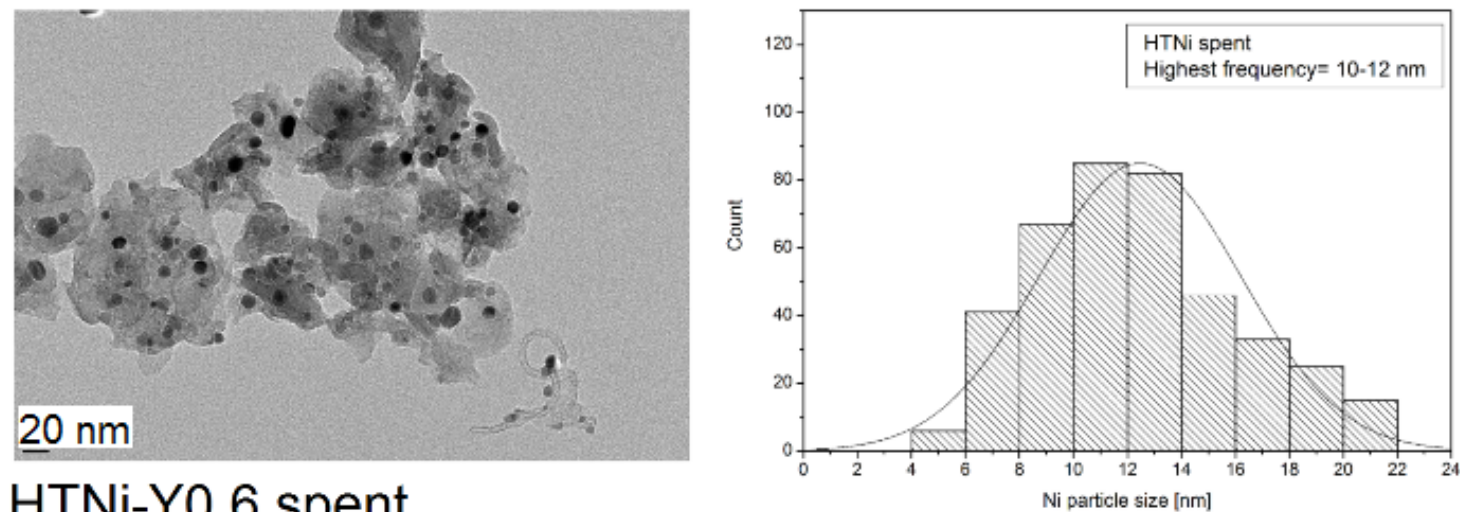

B) HTNi-Y0.6 spent
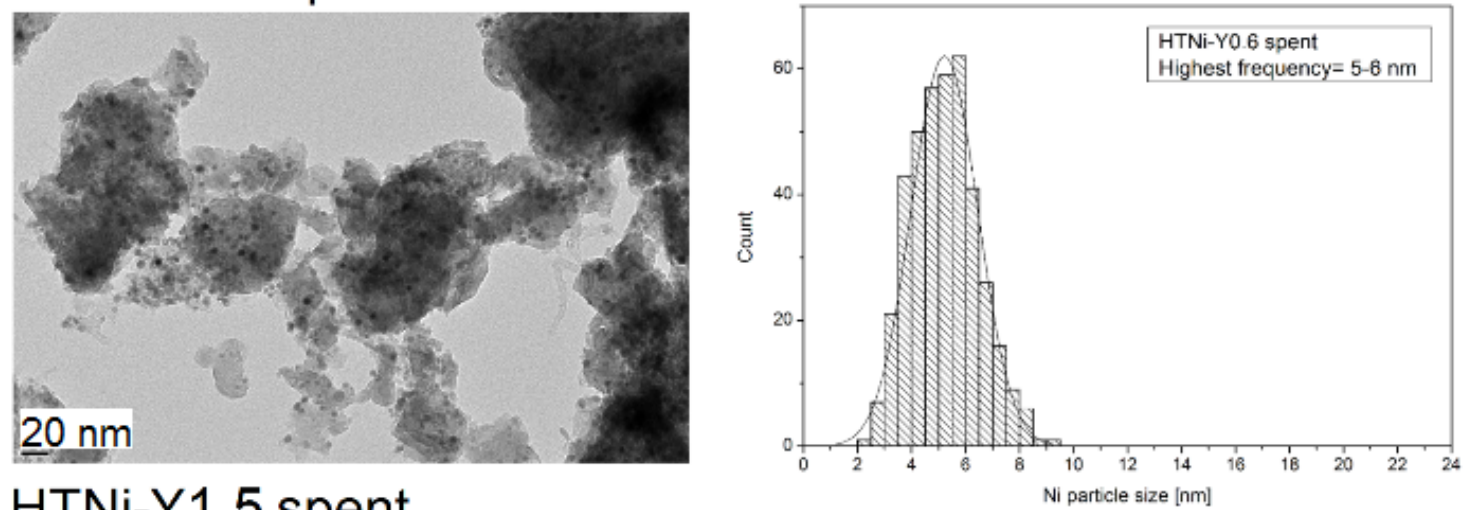

C) HTNi-Y1.5 spent
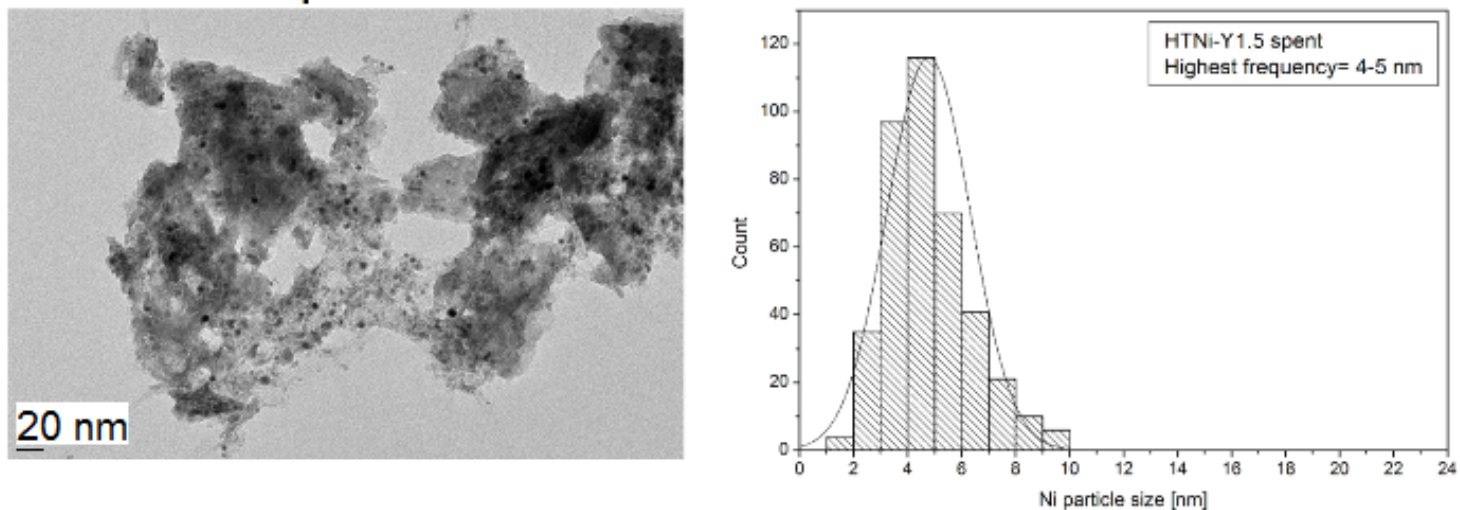

Fig. 12. TEM images of HTNi spent (A), HTNi-Y0.6 spent (B), HTNi-1.5 spent (C), and histograms of Ni particle size distribution. 
Table 1 . The list of reactions of dry methane reforming process $[42,45,46]$.

\begin{tabular}{|c|c|c|c|}
\hline Number & Name & Reaction & $\Delta \mathrm{H}^{\theta}[\mathrm{kJ} / \mathrm{mol}]$ \\
\hline 1 & Dry reforming of $\mathrm{CH}_{4}$ & $\mathrm{CH}_{4}+\mathrm{CO}_{2}=2 \mathrm{CO}+2 \mathrm{H}_{2}$ & 247 \\
\hline 2 & Reverse water gas shift & $\mathrm{CO}_{2}+\mathrm{H}_{2}=\mathrm{H}_{2} \mathrm{O}+\mathrm{CO}$ & 41 \\
\hline 3 & Methanation of $\mathrm{CO}_{2}$ & $\mathrm{CO}_{2}+4 \mathrm{H}_{2}=\mathrm{CH}_{4}+2 \mathrm{H}_{2} \mathrm{O}$ & -165 \\
\hline 4 & Methanation of CO & $\mathrm{CO}+3 \mathrm{H}_{2}=\mathrm{CH}_{4}+\mathrm{H}_{2} \mathrm{O}$ & -206 \\
\hline 5 & Hydrogenation of $\mathrm{CO}_{2}$ & $\mathrm{CO}_{2}+\mathrm{H}_{2}=\mathrm{HCOOH}$ & 15 \\
\hline 6 & Hydrogenation of $\mathrm{CO}_{2}$ & $\mathrm{CO}_{2}+3 \mathrm{H}_{2}=\mathrm{CH}_{3} \mathrm{OH}+\mathrm{H}_{2} \mathrm{O}$ & -49 \\
\hline 7 & Hydrogenation of $\mathrm{CO}$ & $\mathrm{CO}+2 \mathrm{H}_{2}=\mathrm{CH}_{3} \mathrm{OH}$ & -91 \\
\hline 8 & $\begin{array}{l}\text { Dehydration of } \mathrm{CH}_{3} \mathrm{OH} \text { to } \\
\mathrm{CH}_{3} \mathrm{OCH}_{3}\end{array}$ & $2 \mathrm{CH}_{3} \mathrm{OH}=\mathrm{CH}_{3} \mathrm{OCH}_{3}+\mathrm{H}_{2} \mathrm{O}$ & -37 \\
\hline 9 & Reforming of $\mathrm{CH}_{3} \mathrm{OCH}_{3}$ & $\mathrm{CH}_{3} \mathrm{OCH}_{3}+\mathrm{H}_{2} \mathrm{O}=2 \mathrm{CO}+4 \mathrm{H}_{2}$ & 205 \\
\hline 10 & Reforming of $\mathrm{CH}_{3} \mathrm{OCH}_{3}$ & $\mathrm{CH}_{3} \mathrm{OCH}_{3}+\mathrm{CO}_{2}=3 \mathrm{CO}+3 \mathrm{H}_{2}$ & 258 \\
\hline 11 & Oxidative coupling of $\mathrm{CH}_{4}$ & $2 \mathrm{CH}_{4}+\mathrm{CO}_{2}=\mathrm{C}_{2} \mathrm{H}_{6}+\mathrm{CO}+\mathrm{H}_{2} \mathrm{O}$ & 106 \\
\hline 12 & Reforming of $\mathrm{C}_{2} \mathrm{H}_{6}$ & $\mathrm{C}_{2} \mathrm{H}_{6}+2 \mathrm{CO}_{2}=4 \mathrm{CO}+3 \mathrm{H}_{2}$ & 430 \\
\hline 13 & Oxidative coupling of $\mathrm{CH}_{4}$ & $2 \mathrm{CH}_{4}+2 \mathrm{CO}_{2}=\mathrm{C}_{2} \mathrm{H}_{4}+2 \mathrm{CO}+2 \mathrm{H}_{2} \mathrm{O}$ & 284 \\
\hline 14 & Reforming of $\mathrm{C}_{2} \mathrm{H}_{4}$ & $\mathrm{C}_{2} \mathrm{H}_{4}+2 \mathrm{CO}_{2}=4 \mathrm{CO}+2 \mathrm{H}_{2}$ & 290 \\
\hline \multicolumn{4}{|c|}{ Reactions of coke } \\
\hline 15 & Methane decomposition & $\mathrm{CH}_{4}=\mathrm{C}_{(\mathrm{s})}+2 \mathrm{H}_{2}$ & 75 \\
\hline 16 & Bouduard reaction & $2 \mathrm{CO}=\mathrm{C}_{(\mathrm{s})}+\mathrm{CO}_{2}$ & -172 \\
\hline 17 & Hydrogenation of $\mathrm{CO}_{2}$ & $\mathrm{CO}_{2}+2 \mathrm{H}_{2}=\mathrm{C}_{(\mathrm{s})}+2 \mathrm{H}_{2} \mathrm{O}$ & -90 \\
\hline 18 & Hydrogenation of CO & $\mathrm{CO}+\mathrm{H}_{2}=\mathrm{C}+\mathrm{H}_{2} \mathrm{O}$ & -131 \\
\hline 19 & Steam on $\mathrm{C}$ & $\mathrm{C}_{(\mathrm{s})}+\mathrm{H}_{2} \mathrm{O}=\mathrm{CO}+\mathrm{H}_{2}$ & 131 \\
\hline
\end{tabular}


Table 2. Elemental composition (XRF), structural parameters (XRD), and textural properties (BET analysis) of double-layered hydroxides modified with nickel and yttrium. Nominal values are presented in brackets.

\begin{tabular}{|c|c|c|c|c|c|c|c|c|c|c|c|}
\hline \multirow{2}{*}{ Catalyst } & \multicolumn{6}{|c|}{ Elemental composition (calcined samples) } & \multicolumn{2}{|c|}{$\begin{array}{l}\text { Structural } \\
\text { parameters } \\
\text { (uncalcined } \\
\text { samples) }\end{array}$} & \multicolumn{3}{|c|}{$\begin{array}{l}\text { Textural properties } \\
\text { (calcined samples) }\end{array}$} \\
\hline & $\begin{array}{l}\mathrm{Mg}^{2+} \\
{[\mathrm{wt} \%]}\end{array}$ & $\begin{array}{l}\mathrm{Al}^{3+} \\
{[\mathrm{wt} \%]}\end{array}$ & $\begin{array}{l}\mathrm{Ni}^{2+} \\
{[\mathrm{wt} \%]}\end{array}$ & $\begin{array}{l}\mathrm{Y}^{3+} \\
{[\mathrm{wt} \%]}\end{array}$ & $\begin{array}{l}\mathrm{Ni}^{2+} / \mathrm{Mg}^{2+} \\
\text { atomic } \\
\text { ratio }\end{array}$ & $\begin{array}{l}\mathrm{M}^{2+} / \mathrm{M}^{3+} \\
\text { atomic } \\
\text { ratio }\end{array}$ & $\mathrm{a}\left[\AA{ }^{1)}\right.$ & $\mathrm{c}[\AA]^{2)}$ & $\begin{array}{l}\mathrm{S}_{\mathrm{BET}} \\
{\left[\mathrm{m}^{2} / \mathrm{g}^{3)}\right.}\end{array}$ & $\begin{array}{l}\mathrm{V}_{\mathrm{p}} \\
{\left[\mathrm{cm}^{3} / \mathrm{g}\right]{ }^{4)}}\end{array}$ & $\begin{array}{l}\mathrm{d}_{\mathrm{p}} \\
{[\mathrm{nm}]^{5)}}\end{array}$ \\
\hline $\mathrm{HTNi}$ & 30 & 12 & 20 & - & $\begin{array}{l}0.29 \\
(0.33)\end{array}$ & $\begin{array}{l}3.6 \\
(3.0)\end{array}$ & 3.06 & 23.45 & 120 & 0.6 & 19 \\
\hline HTNi-Y0.6 & 29 & 12 & 19 & $\begin{array}{l}0.6 \\
(0.6)\end{array}$ & $\begin{array}{l}0.28 \\
(0.33)\end{array}$ & $\begin{array}{l}3.5 \\
(3.0)\end{array}$ & 3.06 & 23.37 & 162 & 0.5 & 11 \\
\hline HTNi-Y1.5 & 32 & 12 & 14 & $\begin{array}{l}1.5 \\
(2.0)\end{array}$ & $\begin{array}{l}0.18 \\
(0.33)\end{array}$ & $\begin{array}{l}3.4 \\
(3.0)\end{array}$ & 3.06 & 23.42 & 192 & 0.6 & 14 \\
\hline
\end{tabular}

1) calculated from the (110) spacing $\mathrm{a}=2 \mathrm{~d}_{(110)}$ as suggested by Cavani et al. [19]

${ }^{2)}$ calculated from XRD patterns of uncalcined catalysts, from the position of the three first reflections c= $\mathrm{d}_{(003)}+2 \mathrm{~d}_{(006)}+3 \mathrm{~d}_{(009)}$, as suggested by Liu et al. [27]

${ }^{3)}$ specific surface areas calculated from the BET equation 
4) mesopore volumes derived from the BJH desorption method

${ }^{5)}$ pore size distribution obtained from the $\mathrm{BJH}$ desorption method 
Table 3. Basic sites distribution calculated from TPD- $\mathrm{CO}_{2}$ (reduced catalysts).

\begin{tabular}{|l|l|l|l|l|l|l|l|}
\hline \multirow{2}{*}{ Catalyst } & \multicolumn{3}{|l|}{ Basic sites $[\mu \mathrm{mol} / \mathrm{g}]$} & \multicolumn{3}{l|}{ Distribution of basic sites [\%] } \\
\cline { 2 - 8 } & Weak & Medium & Strong & $\begin{array}{l}\text { Total } \\
\text { basicity }\end{array}$ & Weak & Medium & Strong \\
\hline HTNi & 16.4 & 43.9 & 46.3 & 106.6 & 15.4 & 41.2 & 43.4 \\
\hline HTNi-Y0.6 & 12.1 & 32.3 & 11.4 & 55.8 & 21.7 & 57.9 & 20.4 \\
\hline HTNi-Y1.5 & 11.2 & 36.3 & 29.6 & 77.1 & 14.5 & 47.1 & 38.4 \\
\hline
\end{tabular}


Table 4. Average diameters of nickel particles in HTNi-Y catalysts.

\begin{tabular}{|l|l|l|l|}
\hline Catalysts & $\begin{array}{l}\mathrm{d}_{\mathrm{Ni}} \text { from XRD }{ }^{1)} \\
{[\mathrm{nm}]}\end{array}$ & $\begin{array}{l}\mathrm{d}_{\mathrm{Ni}} \text { from TEM } \\
{[\mathrm{nm}]}\end{array}$ & $\begin{array}{l}\mathrm{d}_{\mathrm{Ni}} \text { from } \mathrm{H}_{2} \text { chemisorption }^{3)} \\
{[\mathrm{nm}]}\end{array}$ \\
\hline HTNi & 8 & 27 & 11 \\
Reduced & 5 & 13 & - \\
\hline HTNi-Y0.6 & 6 & 16 & 5 \\
Reduced & 3 & 5 & - \\
Spent & 6 & 14 & 5 \\
\hline HTNi-Y1.5 & 3 & 5 & - \\
Reduced & 6 & & \\
Spent & 3 & 5 & \\
\hline
\end{tabular}

1) based on the Scherrer equation, from the width at half-maximum of the XRD reflections at $2 \theta$ ca. $53^{\circ}$

${ }^{2)}$ average diameter of Ni particles obtained from TEM image

3) calculated from $d=971 /(\% \mathrm{D})$ based on the assumption of spherical crystallites of uniform size 
Table 5. Nickel dispersion and catalytic activity results expressed in percentage and as turnover frequency.

\begin{tabular}{|c|c|c|c|c|c|c|c|c|c|c|c|}
\hline \multirow{2}{*}{ Catalyst } & \multirow{2}{*}{$\begin{array}{l}\text { Nickel } \\
\text { dispersion } \\
{[\%]}\end{array}$} & \multicolumn{3}{|c|}{$\begin{array}{l}\text { Conversion at } 700^{\circ} \mathrm{C} \\
{[\%]^{1)}}\end{array}$} & \multicolumn{2}{|c|}{$\begin{array}{l}\text { TOF at } 700^{\circ} \mathrm{C} \\
{\left[10^{-3} \mathrm{~s}^{-1}\right]^{1), 2)}}\end{array}$} & \multicolumn{3}{|c|}{$\begin{array}{l}\text { Conversion at } 750^{\circ} \mathrm{C} \\
{[\%]^{1)}}\end{array}$} & \multicolumn{2}{|c|}{$\begin{array}{l}\text { TOF at } 750^{\circ} \mathrm{C} \\
{\left[10^{-3} \mathrm{~s}^{-1}\right]^{1), 2)}}\end{array}$} \\
\hline & & $\mathrm{CH}_{4}$ & $\mathrm{CO}_{2}$ & $\mathrm{H}_{2} / \mathrm{CO}$ & $\mathrm{CH}_{4}$ & $\mathrm{CO}_{2}$ & $\mathrm{CH}_{4}$ & $\mathrm{CO}_{2}$ & $\mathrm{H}_{2} / \mathrm{CO}$ & $\mathrm{CH}_{4}$ & $\mathrm{CO}_{2}$ \\
\hline HTNi & 8.9 & 66.0 & 76.0 & 0.87 & 104.6 & 131.1 & 82.5 & 86.5 & 0.93 & 130.7 & 149.2 \\
\hline HTNi-Y0.6 & 17.7 & 74.0 & 78.0 & 0.93 & 64.8 & 71.6 & 86.6 & 87.7 & 0.96 & 75.8 & 80.9 \\
\hline HTNi-Y1.5 & 19.8 & 76.2 & 80.8 & 0.92 & 130.0 & 140.1 & 88.0 & 90.1 & 0.96 & 150.2 & 156.2 \\
\hline
\end{tabular}

Calculated basing on activity test at appropriate temperature

2) Based on the equation (4) 
Table 6 Stability results showing initial activity and after 5 and 10 hours tests, and the relative change due to deactivation.

\begin{tabular}{|l|l|l|}
\hline Catalyst & $\mathrm{CO}_{2}$ conversion [\%] & $\mathrm{CH}_{4}$ conversion [\%] \\
\hline HTNi & 75.7 & 74.0 \\
Initial & 74.3 & 72.3 \\
After 5h & 72.1 & 69.9 \\
After 10h & 1.8 & 2.3 \\
$\Delta:$ relative change after 5h' & \\
$\Delta:$ relative change after $10 \mathrm{~h}^{1)}$ & 4.8 & 5.5 \\
\hline HTNi-Y0.6 & 78.1 & \\
Initial & 76.7 & 73.9 \\
After 5h & 74.3 & 70.8 \\
After 10h & 1.8 & 69.0 \\
$\Delta:$ relative change after $5 \mathrm{~h}^{1)}$ & 4.9 & 4.2 \\
$\Delta:$ relative change after $10 \mathrm{~h}^{1)}$ & 4.9 & 6.6 \\
\hline HTNi-Y1.5 & 78.6 & 74.4 \\
Initial & 78.3 & 73.9 \\
After 5h & 77.8 & 0.7 \\
After 10h & 0.4 & 1.5 \\
$\Delta:$ relative change after $5 \mathrm{~h}^{1)}$ & 1.0 & \\
$\Delta:$ relative change after $10 \mathrm{~h}^{1)}$ & & \\
\hline
\end{tabular}

${ }^{1)}$ Based on equation (3) 